\title{
Striatopallidal Neuron NMDA Receptors Control Synaptic Connectivity, Locomotor, and Goal-Directed Behaviors
}

\author{
Laurie Lambot, ${ }^{1}$ Elena Chaves Rodriguez, ${ }^{1}$ Delphine Houtteman, ${ }^{1} \odot$ Y uquing Li, ${ }^{2}$ Serge N. Schiffmann, ${ }^{1}$ David Gall, ${ }^{1 *}$ \\ and ${ }^{\circ}$ Alban de Kerchove d'Exaerde ${ }^{1 *}$ \\ ${ }^{1}$ Laboratory of Neurophysiology, ULB Neuroscience Institute, Université Libre de Bruxelles (ULB), Brussels B-1070, Belgium, and 2Department of \\ Neurology, College of Medicine, University of Florida, Gainesville, Florida 32610
}

The basal ganglia (BG) control action selection, motor programs, habits, and goal-directed learning. The striatum, the principal input structure of BG, is predominantly composed of medium-sized spiny neurons (MSNs). Arising from these spatially intermixed MSNs, two inhibitory outputs form two main efferent pathways, the direct and indirect pathways. Striatonigral MSNs give rise to the activating, direct pathway MSNs and striatopallidal MSNs to the inhibitory, indirect pathway (iMSNs). BG output nuclei integrate information from both pathways to fine-tune motor procedures and to acquire complex habits and skills. Therefore, balanced activity between both pathways is crucial for harmonious functions of the BG. Despite the increase in knowledge concerning the role of glutamate NMDA receptors (NMDA-Rs) in the striatum, understanding of the specific functions of NMDA-R iMSNs is still lacking. For this purpose, we generated a conditional knock-out mouse to address the functions of the NMDA-R in the indirect pathway. At the cellular level, deletion of GluN1 in iMSNs leads to a reduction in the number and strength of the excitatory corticostriatopallidal synapses. The subsequent scaling down in input integration leads to dysfunctional changes in BG output, which is seen as reduced habituation, delay in goaldirected learning, lack of associative behavior, and impairment in action selection or skill learning. The NMDA-R deletion in iMSNs causes a decrease in the synaptic strength of striatopallidal neurons, which in turn might lead to a imbalanced integration between direct and indirect MSN pathways, making mice less sensitive to environmental change. Therefore, their ability to learn and adapt to the environment-based experience was significantly affected.

Key words: goal-directed behavior; NMDA receptor; spine morphology; striatopallidal neuron; striatum; synaptic transmission

\section{Significance Statement}

The striatum controls habits, locomotion, and goal-directed behaviors by coordinated activation of two antagonistic pathways. Insofar as NMDA receptors (NMDA-Rs) play a key role in synaptic plasticity essential for sustaining these behaviors, we generated a mouse model lacking NMDA-Rs specifically in striatopallidal neurons. To our knowledge, this is the first time that a specific deletion of inhibitory, indirect pathway medium-sized spiny neuron (iMSN) NMDA-Rs has been used to address the role of these receptors in the inhibitory pathway. Importantly, we found that this specific deletion led to a significant reduction in the number and strength of the cortico-iMSN synapses, which resulted in the significant impairments of behaviors orchestrated by the basal ganglia. Our findings indicate that the NMDA-Rs of the indirect pathway are essential for habituation, action selection, and goal-directed learning.

\section{Introduction}

The striatum serves as the primary input nucleus of the basal ganglia (BG) circuitry and therefore receives glutamatergic excit-

Received July 17, 2015; revised Feb. 23, 2016; accepted March 7, 2016.

Author contributions: L.L., S.N.S., D.G., and A.d.K.d.E. designed research; L.L. and E.C.R. performed research; D.H. and Y.L. contributed unpublished reagents/analytic tools; L.L. and E.C.R. analyzed data; L.L., S.N.S., D.G., and A.d.K.d.E. wrote the paper.

This work was supported by the Fondation Médicale Reine Elisabeth (FMRE)-Belgium, FRS-Fonds de la Recherche Scientifique (FNRS)-Belgium, Interuniversity Attraction Pole from Belgian Federal Scientific Affairs (Grant P7/10), and Action de Recherche Concertée. L.L. was supported by a Fonds pour la Formation á la Recherche dans I'Industrie et dans l'Agriculture (FRIA) doctoral fellowship from the FRS-FNRS (Belgium) and Van Buuren funds. E.C.R. was supported by a FRIA doctoral fellowship from the FRS-FNRS. A.d.K.d.E. is a Senior Research Associate of the FRS-FNRS and is an investigator of Walloon Excellence in Lifesciences \& BIOtechnology. We thank Brittany Davis atory inputs from the cortex and the thalamus. The striatal projection neurons (so-called medium-spiny neurons, MSNs) are characterized by their high spine density and their GABAergicinhibitory outputs (for review, see Gerfen and Surmeier, 2011). From these spatially intermixed MSNs arise two inhibitory outputs forming two main efferent pathways called the direct and the indirect pathways. The striatonigral neurons, expressing the do-

for helpful comments and corrections, Frederic Bollet-Quivogne from the Light Microscopy Facility for comments on microscopy, and Laetitia Cuvelier for expert technical assistance.

The authors declare no competing financial interests.

D. Gall's present address: Laboratory of Physiology and Pharmacology, Université Libre de Bruxelles, Brussels B-1070, Belgium. 
pamine $D_{1}$ receptors, form the direct pathway and project to the substantia nigra pars reticulata $(\mathrm{SNr})$ and the internal globus pallidus. The striatopallidal neurons, expressing dopamine $\mathrm{D}_{2}$ receptors and adenosine $A_{2 A}$ receptors ( $A_{2 A}$ Rs; Schiffmann et al., 2007 ), form the indirect pathway and project to the external globus pallidus (GPe). This pathway, in turn, inhibits the subthalamic nucleus, which excites output nuclei. BG output nuclei integrate information from both pathways to fine-tune motor processes; therefore, the direct pathway MSNs (dMSNs) facilitate motor activity and the indirect pathway MSNs (iMSNs) inhibit motor activity (Tepper et al., 2007; Durieux et al., 2009, 2012; Bateup et al., 2010; Kravitz et al., 2010, 2012). Moreover, these segregated circuits play an essential role, not only in simple motor functions, but also in controlling goal-directed actions and habit formation (Albin et al., 1989; Graybiel et al., 1994; Yin and Knowlton, 2006; Shan et al., 2014). Importantly, the disruption of either neuronal subpopulation has been implicated in major neuropsychiatric disorders such as Parkinson's disease and Huntington's disease, as well as in drug addiction (Albin et al., 1989; Everitt and Robbins, 2005; Day et al., 2006; Hyman et al., 2006; Kreitzer and Malenka, 2007; Redgrave et al., 2010).

At the cellular and synaptic level, the transfer of information throughout BG circuitry undergoes major dynamic changes. The striatum, which receives mainly glutamatergic afferents, represents a major site of synaptic plasticity (Bolam et al., 2000; Gerdeman et al., 2003; Gerfen and Surmeier, 2011). Because glutamate $N$-methyl-D-aspartate receptors (NMDA-Rs) contribute to this process, they play a crucial role in mediating learning and memory and in many other forms of experience-dependent plasticity (Malenka and Bear, 2004). Previous work has shown that MSNs have a large number of NMDA-Rs (Albin et al., 1992; Standaert et al., 1999) that are essential to striatal function, contributing to locomotion and goal-directed behaviors (Heusner and Palmiter, 2005; Dang et al., 2006; Ohtsuka et al., 2008; Jin and Costa, 2010; Parker et al., 2011; Beutler et al., 2011b; Eldred and Palmiter, 2013; Darvas and Palmiter, 2015). Moreover, some studies have reported that glutamate signaling, specifically through NMDA-Rs in dMSNs, is required for the long-term changes taking place during repeated exposure to addictive drugs or in cognitive flexibility (Heusner and Palmiter, 2005; Beutler et al., 2011a; Darvas and Palmiter, 2015). However, so far, the potential involvement of iMSN NMDA-Rs in various forms of behavior has not been addressed.

In this study, we used a conditional NMDA-R knock-out (cKO) mouse specifically targeting striatopallidal neurons to address the functions of the NMDA-R in iMSNs. We generated a cell-type-specific genetic model in which Cre recombinase selectively ablates the essential GluN1 subunit expression of NMDA-R in striatopallidal neurons (Monyer et al., 1992). This conditional gene knock-out strategy allowed us to characterize the physiological functions of iMSN NMDA-R signaling within the BG circuitry. We found that the GluN1-ablated iMSNs demonstrated abnormal neuronal morphology, including reduced number and size of spines. The reduction in spine number and size correlated with an overall reduction in functional glutamatergic synaptic inputs. Furthermore, the $\mathrm{cKO}$ mice were impaired in goal-

*D.G. and A.d.K.d.E. contributed equally to this work.

Correspondence should be addressed to Alban de Kerchove d'Exaerde, Laboratory of Neurophysiology, ULB Neuroscience Institute, Université Libre de Bruxelles (ULB), 808 Route de Lennik, B-1070 Brussels, Belgium. E-mail: adekerch@ulb.ac.be.

DOI:10.1523/JNEUROSCI.2717-15.2016

Copyright $\odot 2016$ the authors $\quad 0270-6474 / 16 / 364977-17 \$ 15.00 / 0$ directed behavior, habituation, and action selection during a motor learning task. These behavioral impairments likely reflected the disruption in the synaptic function of neurons in the iMSN pathway. Together, these data demonstrate that imbalanced NMDA-R signaling in iMSNs disrupts the orchestrated activities across BG circuits.

\section{Materials and Methods}

Animals

To generate a mutant strain of mice lacking NMDA-R in iMSNs, Adora2a-Cre ${ }^{+/-}$transgenic mice expressing the Cre recombinase under the control of the striatopallidal specific adenosine $A_{2 A}$ receptor (Adora2a) promoter (Durieux et al., 2009) were bred with Grin1 floxed mice in which the two loxP sites flanked exon 9 and 10 of the Grin 1 gene and separated by a distance of $2.1 \mathrm{~kb}$ (Dang et al., 2006). Double transgenic mice Adora2a-Cre ${ }^{+/-}$Grin $1^{\text {lox/lox }}\left(\mathrm{A}_{2 \mathrm{~A}} \mathrm{Cre}^{+} \mathrm{Grin} 1\right)$ were obtained and then crossed with homozygous Rosa26-Lox-Stop-Lox-YFP reporter mice (Srinivas et al., 2001). The breeding between $\mathrm{A}_{2 \mathrm{~A}} \mathrm{Cre}^{+/-}$ Grin $1^{\text {lox/lox }}$ and Grin $1^{\text {lox/lox }}$ Rosa26-LSL-YFP mice results in $50 \%$ of $\mathrm{A}_{2 \mathrm{~A}} \mathrm{Cre}^{+/-}$Grin $1^{\text {lox/lox}}$ Rosa26YFP (cKO mice) and 50\% Grin1 ${ }^{\text {lox/lox }}$ Rosa26-LSL-YFP (Control) mice; the latter were used as controls for behavioral tests. Cells expressing the Cre recombinase in the $\mathrm{CKO}$ mouse line were identified by YFP fluorescence. These cells were considered to be GluN1 depleted. $\mathrm{A}_{2 \mathrm{~A}}$ Cre mice were also crossed directly with Rosa26Lox-Stop-Lox-YFP mice to obtain the $\mathrm{A}_{2 \mathrm{~A}} \mathrm{Cre}^{+/-}$Rosa26YFP mice, which were also used as controls for electrophysiological recordings and immunostaining. The YFP expression of $\mathrm{A}_{2 \mathrm{~A}} \mathrm{Cre}^{+/-}$Rosa26YFP allows the identification of the wild-type (WT) iMSNs. All the mice of the $\mathrm{A}_{2 \mathrm{~A}}$ Cre, Rosa26YFP, and Grin1 lines were first backcrossed for at least four generations to the C57BL6 background and then used to produce the experimental mice. All procedures were performed according to Institutional Animal Care Committee guidelines and were approved by the local ethics committees. All efforts were made to minimize the number of animals used and their suffering.

\section{Striatal cell dissociation and FACS}

Only mice homozygous for the transgene Rosa26-YFP $\left(\mathrm{A}_{2 \mathrm{~A}} \mathrm{Cre}^{-1-}\right.$ Grin $1{ }^{\text {lox/lox}}$ Rosa26YFP and $\mathrm{A}_{2 \mathrm{~A}} \mathrm{Cre}^{+/-}$Rosa26YFP) were used for FACS-based screening (Ena et al., 2013). cKO and control mice were age matched and a minimum of $21 \mathrm{~d}$ old. Control $\left(\mathrm{A}_{2 \mathrm{~A}} \mathrm{Cre}^{-/-} \mathrm{Grin} 1^{\text {lox/lox }}\right.$ Rosa26YFP $\left.{ }^{\text {lox/lox }}\right)$ and cKO $\left(\mathrm{A}_{2 \mathrm{~A}} \mathrm{Cre}^{+/-}\right.$Rosa26YFP $\left.{ }^{\text {lox/lox }}\right)$ adult mice were deeply anesthetized with halothane and brains were removed and sectioned in the coronal plane at $250 \mu \mathrm{m}$ on a VT1000S vibratome (Leica) in a chilled physiological solution containing the following (in mM): 180 sucrose, $2.5 \mathrm{KCl}, 26 \mathrm{NaCO}_{3}, 1.2 \mathrm{Na}_{2} \mathrm{HPO}_{4}, 25$ glucose, 0.1 $\mathrm{CaCl}_{2}, 1 \mathrm{MgCl}_{2}$, and $19 \mathrm{MgSO}_{4}$ bubbled with $5 \% \mathrm{CO}_{2}$ and $95 \%$ oxygen. The striatum was dissected out, first dissociated enzymatically (Protease type XIII $1.5 \mathrm{mg} / \mathrm{ml}$; Sigma-Aldrich) in HBSS trehalose $10 \%$ and then triturated. To remove the excess debris, the cell suspension was subjected to a discontinuous density gradient medium of iodixanol (OptiPrep) at $1900 \mathrm{rpm}$ for $15 \mathrm{~min}$ and then resuspended in a buffered medium (L-15 Leibovitz medium with $\mathrm{CO}_{2}$ without phenol red; 10 mM HEPES) and filtered twice through a $40 \mu \mathrm{m}$ cell strainer (Falcon; BDBiosciences). Cells were treated with Hoechst 33342 (1:4000; H3570; Invitrogen) to label dead cells and sorted on a FACSAria cell sorter (BDBiosciences) for fluorescein isothiocyanate signal (detecting YFP) and Fl3 (detecting Hoechst). First, samples obtained from WT mice were used to set the forward and side scatter to determine the optimal criteria for the sorting before each FACS session. Those parameters were then readjusted after elimination of Hoechst ${ }^{-}$cells. The four test samples (striatal Hoechst ${ }^{-} /$ $\mathrm{YFP}^{-}$and Hoechst ${ }^{-} / \mathrm{YFP}^{+}$from control and $\mathrm{cKO}$ mice) were then analyzed and neurons were sorted. Sorted cells were collected directly in Qiagen RLT lysis buffer to proceed with the RNA extraction. Each sample was a collection of cells pooled from 2-4 animals. All steps of this protocol were performed at $4^{\circ} \mathrm{C}$ except for the enzymatic dissociation, which was performed at $34^{\circ} \mathrm{C}$. 
Table 1. Primers used for $q \mathrm{PCR}$ analysis

\begin{tabular}{lll}
\hline Gene & Forward & Reverse \\
\hline RER-1 & 5' CCACCTAAACCTTTTCATTGCG 3' & 5' TTTGTAGCTGCGTGCCAAAAT 3' $^{\prime}$ \\
RPL13 & 5' (CCGTGGCGATTGTGAA 3' & 5' TCATTGTCCTTCTGTGCAGGTT 3' \\
GAPDH & 5' TGTGTCCGTCGTGGATCTGA 3' & 5' CCTGCTTCACCACCTTCTTGA 3' \\
$\beta$-ACtin & 5' AACCGTGAAAAGATGACCCAG 3' $^{\prime}$ & 5' GCCTGGATGGCTACGGCTACGTACATG 3' \\
GluN1 & 5' ACTGGCCGTGTGGAATTCA 3' & 5' CATTGTAGATGCCCACTTGCA 3' \\
\hline
\end{tabular}

$R N A$ extraction, reverse transcription, and $q R T-P C R$

Total RNA was extracted from sorted cells using RNeasy Microkit (Qiagen). All RNA samples were treated with an RNase Free DNase Set (Qiagen). RNA quality and quantities were assessed by gel electrophoresis on a RNA assay chips (HighSens analysis kit; Bio-Rad). Purified total RNA was used to synthesize a first-strand cDNA using an MMLV-RT kit (Invitrogen) and random hexamer (Roche). qRT-PCR analysis was performed with $200 \mathrm{pg}$ of cDNA as a template with Power SYBR green (Applied Biosystems) on the ABI 7500 Fast Real Time PCR system (Applied Biosystems). Primers used for qRT-PCR analysis are listed in Table 1. All primers were designed using Primer Express (Applied Biosystems) on different exons to avoid genomic DNA amplification. The gene amplification efficiency was measured and only primers with an amplification efficiency of $90 \%$ were used. Ct (threshold cycle) values for each gene were normalized to the Ct value for RER-1, RPL13, and GAPDH to obtain relative expression level using qBASE 1.3.4 (Hellemans et al., 2007). The sample obtained from control iMSNs was used as reference and set at an arbitrary value of 1 (Ena et al., 2013). This study was validated using qRT-PCR on three independent biological replicates.

\section{Acute brain slice preparation}

In the rodent striatum, excitatory synapse density rises markedly between postnatal day 10 (P10) and P21 (Tepper et al., 1998). Therefore, we only worked with P21-P45 mice. Those animals were deeply anesthetized using halothane and killed by decapitation. Brains were rapidly removed and immersed in ice-cold cutting solution containing the following (in mM): 110 choline, $2.5 \mathrm{KCl}, 1.25 \mathrm{NaH}_{2} \mathrm{PO}_{4}, 7 \mathrm{MgCl}_{2}, 0.5 \mathrm{CaCl}_{2}, 25$ $\mathrm{NaHCO}_{3}$, and 7 glucose equilibrated with a $95 \% \mathrm{O}_{2}$ and $5 \% \mathrm{CO}_{2}$ mixture. Next, $220 \mu \mathrm{m}$ cortico-striatal coronal slices were prepared (Leica VT1000S vibratome) in the cutting solution. Slices were washed, then transferred to a chamber filled with a standard artificial CSF (aCSF) containing the following (in mM): $127 \mathrm{NaCl}, 2.5 \mathrm{KCl}, 1.25 \mathrm{NaH}_{2} \mathrm{PO}_{4}, 2$ $\mathrm{MgCl}_{2}, 4 \mathrm{CaCl}_{2}, 25 \mathrm{NaHCO}_{3}$, and 10 glucose equilibrated with a $95 \% \mathrm{O}_{2}$ and $5 \% \mathrm{CO}_{2}$. Slices were left in the chamber at $34^{\circ} \mathrm{C}$ for at least $1 \mathrm{~h}$.

\section{Electrophysiology}

At the end of the recovery period, slices were placed in a submersion-type chamber at room temperature with $1.5 \mathrm{ml} \mathrm{min}{ }^{-1}$ flux rate of aCSF saturated with $95 \% \mathrm{O}_{2}$ and $5 \% \mathrm{CO}_{2}$. Striatopallidal neurons were recorded at room temperature in acute brain slices obtained as described in the previous section, Acute brain slice preparation. Somatic whole-cell patch-clamp recordings were obtained from $\mathrm{YFP}^{+}$neurons from $\mathrm{cKO}$ and compared with a control $\mathrm{A}_{2 \mathrm{~A}} \mathrm{cre}^{+/-}$Rosa26YFP animal. MSNs within the dorsal striatum were identified with a $63 \times$ water-immersion objective of a Zeiss upright microscope (Axioskop 2FS Plus; Zeiss) and somatic YFP expression was verified routinely using epifluorescence from a source composed of a LED array (OptoLED; Cairn Research) emitting at $488 \mathrm{~nm}$ and coupled to the microscope that was equipped with a dichroic mirror and a high-pass emission filter centered at 505 and $507 \mathrm{~nm}$, respectively. Whole-cell recordings were made under infrared differential interference contrast optics with a back-illuminated CCD camera (iXon+; Andor Technology) with borosilicate-glass patch electrodes (Hilgenberg) obtained with a vertical two-stage puller (PIP 5; HEKA). Pipette resistance was typically 4-7 M $\Omega$. Recordings were started 2 min after obtaining the whole-cell configuration to allow diffusion of the intracellular solution containing the following (in $\mathrm{mM}$ ): 125 potassium methylsulfonate, $7 \mathrm{KCl}, 4 \mathrm{MgCl}_{2}, 10 \mathrm{~K}$-HEPES, $0.1 \mathrm{~K}$-EGTA, $5 \mathrm{Na}_{2}$-phosphocreatine, $0.5 \mathrm{Na}_{2}$-GTP, $4 \mathrm{~K}_{2}$-ATP, and $0.022 \mathrm{CaCl}_{2}(\mathrm{pH}$ 7.2 adjusted with $\mathrm{KOH}$ ). Using $\mathrm{Ca} / \mathrm{Mg} / \mathrm{ATP} / \mathrm{EGTA}$ Calculator version 1 (Winmacs), the EGTA and calcium concentrations were adjusted to reach a basal intracellular free calcium concentration of $102.3 \mathrm{~nm}$ (adapted from Seutin and Engel, 2010). The liquid junction potential was evaluated at $12.23 \mathrm{mV}$ using Patcher's Power Tools on Igor Pro and was adjusted for the AP threshold measurements. Current- and voltageclamp recordings were obtained with a Dual EPC-10 operational amplifier (Molecular Devices) interfaced to an OS $\mathrm{X}$ iMac running PatchMaster software (HEKA). The signal for voltage-clamp recordings was filtered at $3 \mathrm{kHz}$ and digitized at $20 \mathrm{kHz}$ and that for current-clamp recordings was filtered at $3 \mathrm{kHz}$ and digitized at $10 \mathrm{kHz}$ using the built-in EPC-10 filter (HEKA).

Passive cellular recordings. Membrane and access resistance measures were extracted in voltage clamp by analyzing current relaxation induced by a $10 \mathrm{mV}$ step change from a holding potential of $-80 \mathrm{mV}$ as described previously (D'Angelo et al., 1995). Membrane capacitance was then obtained after exponential fit to voltage profile in response to current step injection (Golowasch et al., 2009).

Intrinsic excitability. Intrinsic excitability was investigated in current clamp by setting the resting membrane potential at $-80 \mathrm{mV}$ and injecting $1 \mathrm{~s}$ depolarizing steps (from 0 to $250 \mathrm{pA}$ in $10 \mathrm{pA}$ increments). Action potential (AP) frequency was measured by dividing the number of interspike intervals (ISIs) by the time interval between the first and the last spike. Rheobase current was defined as the first current step within a series of $10 \mathrm{pA}$ steps beginning at $0 \mathrm{pA}$ that was capable of eliciting at least one AP (Gertler et al., 2008).

Spontaneous EPSCs (sEPSCs). To isolate spontaneous excitatory synaptic input, cells were held at the estimated reversal potential for inhibitory input of $\sim-60 \mathrm{mV}$. Data were then acquired and analyzed using the MiniAnalysis program (Synaptosoft). For the detection of spontaneous currents, the threshold detection for negative events was first determined as twice the SD of the average baseline noise. This threshold was then used to automatically detect events, which were visually controlled, and permitted us to quantify frequencies and amplitudes of those spontaneous synaptic events. "Rise time" and "decay $\tau$ " of sEPSCs are, respectively, the time to rise from $20-80 \%$ of peak amplitude and the monoexponential time constant of decay. Recordings lasted from 3 to 10 min for each cell to obtain 100 to 1000 events.

Evoked EPSCs (eEPSCs). In response to cortical input stimulation within the corpus callosum, excitatory synaptic currents were recorded at $-70 \mathrm{mV}$ and $+40 \mathrm{mV}$, repeated 10 times, with $50 \mu \mathrm{M}$ picrotoxin (Sigma-Aldrich). AMPA receptor (AMPA-R)-mediated current was measured as the peak current at $-70 \mathrm{mV}$ and NMDA-R-mediated current was estimated at $+40 \mathrm{mV}$ as the current amplitude $50 \mathrm{~ms}$ after the AMPA-R peak at $-70 \mathrm{mV}$ measured previously. The ratio between NMDA and AMPA current (NMDA/AMPA ratio) was calculated by dividing the estimated NMDA-R current by the peak AMPA-R current.

Spontaneous IPSCs (sIPSCs). sIPSCs were recorded by the use of a high-chloride $\mathrm{Cs}^{+}$-based intracellular solution containing the following (in mM): $127 \mathrm{CsCl}, 0.022 \mathrm{CaCl}_{2}, 4 \mathrm{MgCl}_{2}, 10$ HEPES, 0.1 EGTA, $5 \mathrm{Na}_{2}-$ phosphocreatine, $4 \mathrm{~K}_{2}$-ATP, and $0.5 \mathrm{Na}_{2}$-GTP. The membrane potential was held at $-70 \mathrm{mV}$ in the presence of $10 \mu \mathrm{M}$ CNQX (Sigma-Aldrich) to block glutamatergic receptors. Because we used a high-chloride $\mathrm{Cs}^{+}{ }_{-}$ based intracellular solution to record sIPSCs, the $\mathrm{GABA}_{\mathrm{A}}$-mediated currents were inward currents when membrane potential was held at negative values because the reversal potential of $\mathrm{Cl}^{-}$channel under such condition is $\sim 0 \mathrm{mV}$. Data were then acquired and analyzed as described for sEPSCs.

Peak-scaled nonstationary fluctuation analysis (NSFA). NSFA was performed from an ensemble of sEPSCs at a holding potential of $-60 \mathrm{mV}$ to estimate the mean single-channel conductance of AMPA-Rs using Mini Analysis software (Benke et al., 2001; Hartveit and Veruki, 2007). Unitary sEPSCs were carefully selected for analysis by visual inspection based on the following criteria: fast rise time to allowing for precise alignment, stable baseline, and exponential decay. The sEPSCs were aligned by their point of maximal rise and averaged. The average response waveform was scaled to the peak of individual responses and the variance of the fluctuation of the decay around the mean was calculated. This variance was binned (100 bins of equal current decrement) and plotted versus the mean current amplitude of the decay. The shape of the varianceamplitude relationship was fitted with the following equation: $\sigma 2=i I-$ 
$I 2 / N+b$ where $i$ was the mean single-channel AMPA-R current, $I$ the mean current, $N$ the number of channels activated at the peak, and $b$ the baseline variance. Parameter $i$ was estimated as the slope of the linear fit of the first portion of the parabola because the equation becomes linear when AMPA-R open probability gets close to zero. The number of open channels at the peak was calculated by dividing the average mEPSC amplitude by the unitary current $i$.

\section{Immunocytochemistry and biocytin labeling}

To label neurons of interest, $0.5 \%$ biocytin was included in the internal electrophysiological solution (see "Electrophysiology" section, above). After a high-resistance outside-out manipulations, slices were fixed directly in cold $4 \%$ paraformaldehyde (PFA), prepared in $0.01 \mathrm{~mm} \mathrm{PBS}, \mathrm{pH}$ 7.4 , and kept overnight at $4^{\circ} \mathrm{C}$. After several washes in a PBS solution, slices were permeabilized in a $0.1 \%$ Triton X-100 (Sigma-Aldrich) solution prepared in PBS for 90 min. Streptavidin-NL557 (1:2000; NL999; R\&D Systems) was then added to the permeabilization solution and slices were left for $2 \mathrm{~h}$ under stirring at room temperature in the dark. Sections were finally washed several times in a PBS solution and mounted between slide and coverslip (thickness no. 1.5; VWR) using Fluorsave mounting medium (refraction index: 1.358; Calbiochem).

\section{Histology and immunostaining}

Transgenic cKO and $\mathrm{A}_{2 \mathrm{~A}} \mathrm{Cre}^{+/-}$-Rosa26YFP control mice were transcardiacally perfused with a $0.1 \mathrm{M}$ PBS solution followed by PFA $4 \%$ in $0.1 \mathrm{M}$ PBS solution. Brains were removed and postfixed in PFA $4 \%$ overnight at $4^{\circ} \mathrm{C}$. The $100-\mu \mathrm{m}$-thick $10^{\circ}$ tilted parasagital sections were cut on a vibratome through all of the striatum (Beurrier et al., 2006). Sections were incubated in $10 \%$ normal horse serum in $0.01 \mathrm{M}$ PBS- $0.1 \%$ Triton $\mathrm{X}-100$ for $60 \mathrm{~min}$ at room temperature to block the nonspecific antibody binding. For single immunofluorescence, sections were then incubated overnight at $4^{\circ} \mathrm{C}$ with the chicken anti-GFP antibody (1:2000; ab13970; Abcam) in 1\% normal horse serum, $0.01 \mathrm{M}$ PBS, and $0.1 \%$ Triton X-100. Antibody was then detected using a goat anti-chicken Alexa Fluor 488 (1:400; A11039; Invitrogen). For the double-immunofluorescence YFP/ enkephalin, antigen retrieval was performed by preincubation of slides in sodium citrate buffer $(10 \mathrm{~mm}$; $\mathrm{pH} 8.5)$ at $80^{\circ} \mathrm{C}$ for $30 \mathrm{~min}$ and rinsed in PBS $(0.01 \mathrm{M})$. Sections were blocked and permeabilized as above, then coincubated overnight at $4^{\circ} \mathrm{C}$ with the chicken polyclonal anti-GFP antibody (1:2000; ab13970; Abcam) and the rabbit polyclonal anti pre-proenkephalin antibody (1:500; RA14124; Neuromics) in 0.01 м PBS- $0.1 \%$ Triton X-100. After several washes, the antibodies were detected using a goat anti-chicken Alexa Fluor 488 (1:400; A11039; Invitrogen) and a donkey anti-rabbit IgG coupled with an Alexa Fluor 594 (1/200; 711-585152; Jackson ImmunoResearch) for the pre-pro-enkephalin. Hoechst 33342 was used for nuclear staining (1:5000; H3570; Invitrogen). Sections were rinsed and mounted between slide and coverslip using FluorSave mounting medium.

\section{Confocal microscopy}

Serial optical sections ( $Z$-stacks) were acquired on a laser-scanning confocal system (LSM 780; Zeiss) mounted on an Axio Observer Z1 inverted microscope (Zeiss) equipped with a GaAsP spectral detector. The excitation beam of an argon laser $(488 \mathrm{~nm})$ was used for the detection of the YFP labeled by Alexa Fluor 488 fluorophore with a band-pass emission filter of 500-600 nm. For biocytin stainining with NL557 and enkephalin immunostaining with Alexa Fluor 594, excitation was provided by an $\mathrm{He}-\mathrm{Ne}$ laser $(543 \mathrm{~nm})$ and fluorescence was measured between 560 and $650 \mathrm{~nm}$ or 585 and $700 \mathrm{~nm}$, respectively. A $405 \mathrm{~nm}$ blue laser diode was used for excitation of Hoechst nuclear labeling with band-pass emission filter of 410- $550 \mathrm{~nm}$. Imaging of single-immunofluorescence YFP was performed with an EC Plan NeoFluar $5 \times / 0.16$ numerical aperture (NA) dry objective, total dendrite arborization with a $20 \times / 0.8 \mathrm{NA}$ dry objective, double-immunofluorescence YFP/enkephalin with a C-Apochromat $40 \times / 1.1 \mathrm{NA}$ water-immersion objective, and dendrite endings with an $\alpha$ Plan-Apochromat $63 \times / 1$.46 NA oil-immersion objective (Zeiss). The ideal sampling density during acquisition, which depends on the optics of the microscope, was calculated for dendrite endings in the axial direction as $\left(\Delta y=\frac{\lambda_{e x}}{4 n}(1-\cos \alpha)\right)$ and in the lateral direction as $\left(\Delta x=\frac{\lambda_{e x}}{8 n \sin \alpha}\right)$ based on Nyquist criterion. Therefore, the dendrite endings were sampled with a lateral sampling distance of $40 \mathrm{~nm}$ and an axial sampling distance of $120 \mathrm{~nm}$. $Z$-stack scans were acquired with constant imaging parameters using ZEN 2010 software (Zeiss). Figures were prepared using Fiji software and Adobe Illustrator.

\section{Imaging processing}

The postacquisition computer image processing consists of three stages: (1) image deconvolution, (2) correction for image mismatch, and (3) surface rendering 3D image reconstruction.

Deconvolution. Stacks of images were processed first with Huygens-II deconvolution software (Scientific Volume Imaging). During the deconvolution step, an algorithm (Classic Maximum Likelihood Estimation) determines a point spread function, which is used to calculate, for each pixel of each acquired image in a $Z$-series, the statistical likelihood of the exact origin of the photons emitted by its fluorescent source.

Correction for image mismatch. A mismatch correction factor was calculated from the multiple $Z$-series of the same neuron acquisition (tile scan). This correction factor consisted of an offset shift parameter (along the $x, y$, and $z$ axes) necessary to stitch perfectly these $Z$-series into one $3 \mathrm{D}$ image. This image processing was performed using Fiji software (X_Shifter plugin). The mismatch-corrected $Z$-series were subsequently used for the final 3D reconstruction.

$3 D$ computer reconstruction. Reconstruction of the entire or partial dendritic arbor of the neurons was done by the computer-aided filament tracing function in the 3D image analysis software Imaris (Bitplane). A complementary manual tracing strategy adjusted the automatic reconstruction. Total dendritic arborization reconstruction allowed the study of the dendrite branching and measures of dendrite segment length. Dendrite endings reconstructions allowed us to quantify automatically the density, length, and volume, head and neck volumes, and diameters of spines.

\section{Behavior}

Behavioral experiments were conducted during the light phase of the day with 10- to 16-week-old male mice except for the Pavlovian-toinstrumental transfer (PIT), in which females were used. For each task, three different genotype cohorts were tested: $\mathrm{A}_{2 \mathrm{~A}} \mathrm{cre}^{-1+}$ Grin $1^{\text {lox/lox }}$ Rosa26-YFP (cKO), A ${ }_{2 A}$ cre $^{-1-}$ Grin $1^{\text {lox/lox}}$ Rosa26-YFP (control), and WT C57BL/6 mice. No significant difference was obtained between control mice and WT mice. For this reason, data relative to WT mice are not presented. Behavioral tests were performed in a video-tracking room by an overhead video camera (Ethovision XT; Noldus Information Technology).

Open field. Animals were placed in a square open field $(40 \times 40 \mathrm{~cm})$ for a $1 \mathrm{~h}$ period during 3 consecutive days in 20 lux illumination condition (Durieux et al., 2009). Total distance traveled during the $1 \mathrm{~h}$ session of the $3 \mathrm{~d}$ was reported. In addition, animals were also placed into the open field for a 15 min in 120 lux illumination condition. The open field was virtually divided into peripheral zones and a square, central $20 \times 20 \mathrm{~cm}$ zone. The percentage of time spent in the center versus periphery of the field during the 15 min was reported.

Novel object recognition. The days before the experiment, mice were placed for $10 \mathrm{~min}$ in a square open field $(40 \times 40 \mathrm{~cm})$ in 20 lux illumination with two copies of an unfamiliar object (accommodation phase). The next day, mice were placed in the same open field for $10 \mathrm{~min}$ and were presented with two copies of a new unfamiliar object (habituation phase). After $1 \mathrm{~h}, 1$ of the 2 objects was replaced with a novel object (test phase). The number of visits to both objects was measured. The preference scores for the objects can be further demonstrated by the ratio between novel versus total object explorations during the object phase, which therefore allows comparison between groups (Le Merrer et al., 2013).

Conditioned place preference (CPP). CPP was done in a 3-compartment apparatus consisting of a small middle neutral zone $(6 \times 20 \mathrm{~cm})$ connected to 2 large compartments $(18 \times 20 \mathrm{~cm})$ with different visual patterns on the walls and different tactile patterns on the floors. Three days before the experiment, mice were handled daily and received a single 
saline injection and returned to their home cage. Preconditioning phase (day 1 , for $18 \mathrm{~min}$ ) was as follows: mice were placed in the central neutral area and allowed to explore both compartments. Mice were then randomly assigned to the various experimental groups (unbiased protocol). Conditioning (days 2-7) was as follows: mice were confined to one compartment for $20 \mathrm{~min}$ after intraperitoneal injection of D-amphetamine (Certa; $3 \mathrm{mg} / \mathrm{kg}$ ) on days 2, 4, and 6,or to the other compartment after saline injection on days 3,5 , and 7 . Control mice always received saline. The test phase (day 8 ) occurred when mice were placed in the neutral zone and allowed to explore both compartments freely for $18 \mathrm{~min}$. Results are expressed as the difference between test and preconditioning time spent in the drug-paired compartment (score is in seconds) (Maldonado et al., 1997; Durieux et al., 2009).

Home cage tracking. Ambulatory cage activity was assessed in individually housed mice in standard home cages and expressed as the total distance traveled. Cages were moved into the tracking room $36 \mathrm{~h}$ before the beginning of the acquisition and were then monitored for $12 \mathrm{~h}$ during light phase of the day.

Light and dark box. Mice were individually exposed to a box consisting of a small compartment $(15 \times 20 \times 25 \mathrm{~cm})$ with black walls and black floor that was dimly lit (5 lux) and connected by a $4-\mathrm{cm}$-long tunnel to a large compartment $(30 \times 20 \times 25 \mathrm{~cm})$ with white walls and floor under intense illumination (120 lux). Each animal was placed in the dark compartment facing the tunnel at the beginning of each experiment. The time spent in each compartment was recorded during an 8 min session (Bourin and Hascoët, 2003).

Accelerating rotarod. The rotarod apparatus (accelerating model; Ugo Basile) consisted of a plastic roller ( $3 \mathrm{~cm}$ diameter) with small grooves running along its turning axis (Movie 1). Mice received 4 trials per day for 5 consecutive days. During trials, animals were placed on the rotating rod at a constant speed (4 rpm) and then the rod was accelerated continuously from 4 to $40 \mathrm{rpm}$ over a time period of $300 \mathrm{~s}$. The latency to fall off the rotarod was measured for each session, as well as the number of horizontal retrievals during the last session. Animals that did not fall during the entire experiment were scored as $300 \mathrm{~s}$ (Bearzatto et al., 2006).

Run away. Mice ran along an elevated runway (100 cm long, $1.2 \mathrm{~cm}$ width) with low obstacles (a 1-cm-diameter wooden rod was placed every $10 \mathrm{~cm}$ ) intended to impede their progress. The number of slips of the hind legs on the experimenter side was counted. Mice were placed on one brightly illuminated extremity of the runway and had to run to the dark side, where they found their home cage. Mice were given four trials per hour on the same day (Bearzatto et al., 2006).

Single-pellet reaching task. In this paradigm, mice are trained to extend their forelimbs through a narrow slit to grasp and retrieve food pellets (chocolate pellets, Dustless Precision Pellets Rodent, Purified; Bioserv) positioned at

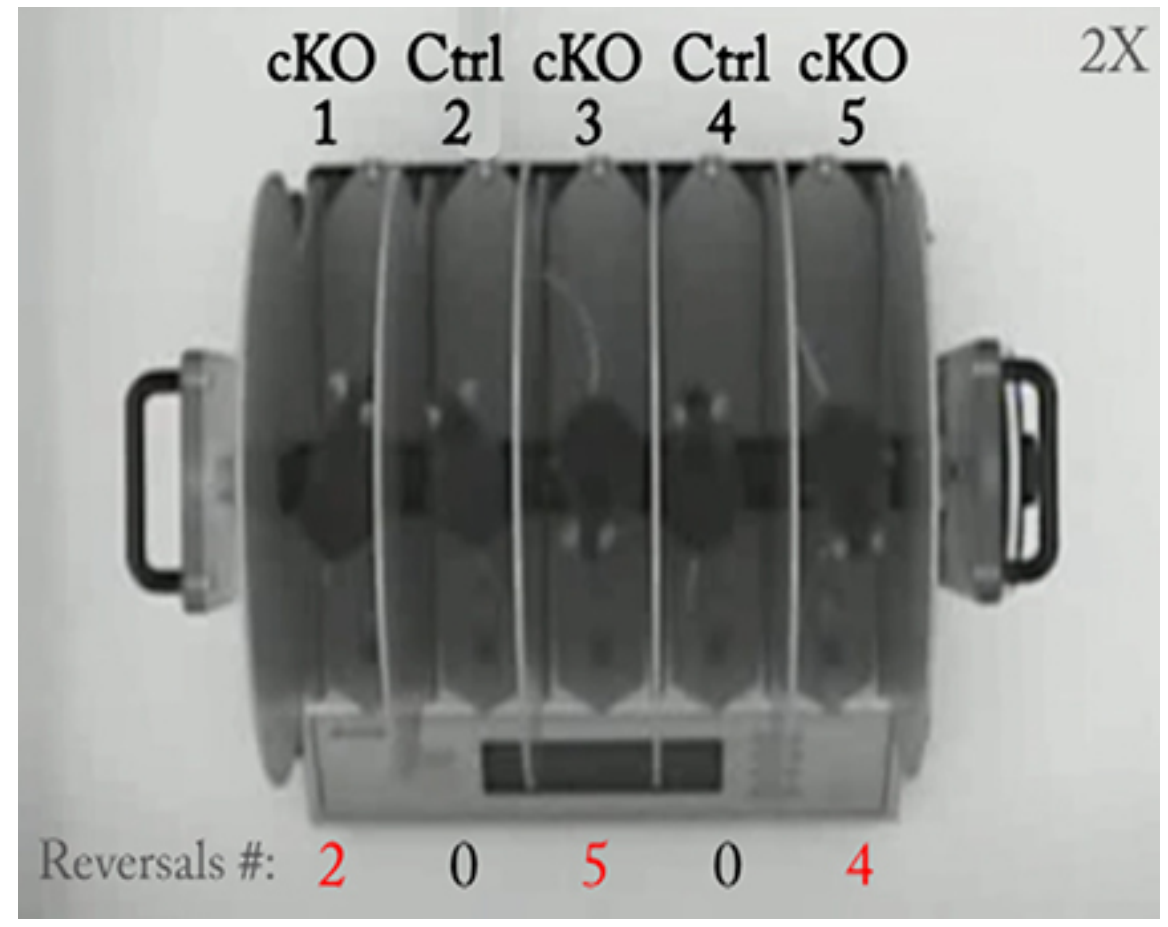

Movie 1. Accelerating Rotarod. Deletion of NMDA-R in iMSN changes the process of action selection during accelerating rotarod without altering motor performance. During the accelerating rotarod task, cKO mice reversed horizontally $\left(180^{\circ}\right)$ in contrast to control mice which keep the same orientation. The number of horizontal reversals $\left(180^{\circ}\right)$ accomplished by mice is reported at the bottom of the image. Movie is shown at $2 \times$ normal speed.
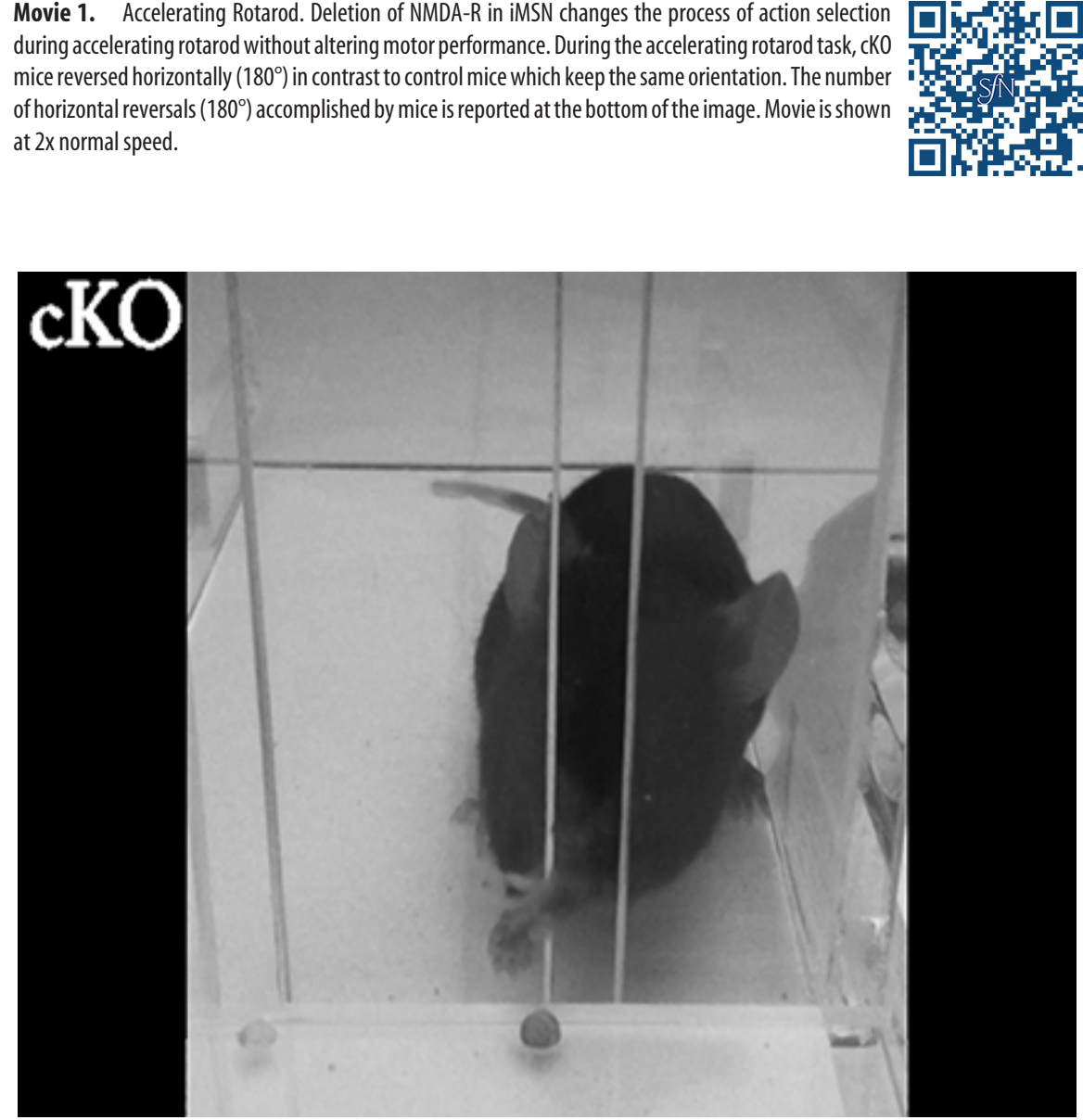

Movie 2. Single Pellet Reaching Task. iMSN NMDA-Rs deletion prevent learning of single pellet reaching task. The average number of success as well as the average success rates during the training period of the single-pellet reaching task are significantly higher for the control mice than the $\mathrm{K} O \mathrm{mice}$. The cKO mice are not able to learn the task since there is no effect of the time on their number of success or their speed of success. Movie is shown at normal speed. 
a fixed location (Movie 2). Mice were placed on a food restriction schedule, kept at $80-85 \%$ of their free-feeding weight, and trained in daily trials. The animals received first the group and the individual habituation session ( $2 \mathrm{~d})$, then the shaping training $(3 \mathrm{~d})$, and then the single-pellet training $(8 \mathrm{~d})$. Two parameters were measured to quantify mouse behavior: the success rate (successful reaches/time) presented as a percentage and the speed of the success rate (successful reaches/total reaching attempts) presented as successful reaches per minute. In most cases, the speed of success continued to increase, even when the success rate plateaued. The protocol used was largely as described previously (Chen et al., 2014).

Grip strength test. Grip strength was assessed on a grip strength meter (Bioseb). Grip strength of the forelimbs was tested by holding the mouse over the grid and moving it down until its front legs grasped the grid. The mouse was then pulled following the axle of the sensor until it released the grid and the maximum force exerted appeared on the display. Individual animals were exposed to five successive measurements. The mean of the three highest values was used for statistical analysis (Chintawar et al., 2009).

Instrumentally conditioned reinforcement. The task was conducted in four identical automated operant chambers (Imetronic), each set in a ventilated, sound-isolated cubicle. Test cages were equipped with a grid floor, a pellet dispenser, and a nose poke (NP) operandum. Mice were placed on a food restriction schedule and kept at $80-85 \%$ of their freefeeding weight. Mice were trained in daily trials of $30 \mathrm{~min}$ during which they learned to use a nose poking device to obtain food pellets (Dustless Precision Pellets Rodent, Purified; Bioserv). Training started with one continuous reinforcement (CRF, every NP rewarded) with additional guaranteed pellet delivery every $120 \mathrm{~s}(\mathrm{CRF}+120,1 \mathrm{~d})$, followed by CRF (every NP rewarded until they reached $80 \mathrm{NP}$ ), fixed ratio trials (FR3, reward on every third NP, 1 d; FR5, reward on every fifth NP until 300 NPs; FR10, reward on every 10th NP until $500 \mathrm{NPs}$ ), and variable ratio (VR) trials (VR10, reward on average every 10th NP until 600 NPs; VR20, reward on average every 20th NP). Once the animals were poking stably on the VR20 schedule for 3 consecutive days, they received food ad libitum again and training continued on a VR20 schedule for 3 more days (devaluation step). Therefore, there are three learning phases: the initial learning phase with the fixed ratio schedule, the late learning phase with the variable ratio schedule, and the devaluation step (adapted from Piccart et al., 2011). The rate of nose poking in each trial was recorded with Imetronic software.

PIT. The PIT (Bertran-Gonzalez et al., 2013) was conducted in the same automated operant chambers (Imetronic) except that two levers replaced the NP operandum of each. In PIT, animals received first an instrumental training phase, then a Pavlovian training phase, and then a probe trial.

Instrumental trainings were administered across $10 \mathrm{~d}$ during which two responses (left and right lever presses) were trained with the two different food outcomes (O1 and $\mathrm{O} 2)$ in two separate daily sessions. Each session ended when 20 outcomes were earned or when $30 \mathrm{~min}$ had elapsed. Training started with one CRF (for $2 \mathrm{~d}$ ), followed by VR trials (VR5 for $3 \mathrm{~d}$; VR10 for $5 \mathrm{~d}$ ). Learning during instrumental training was assessed using the number of lever presses. This rate of lever press was calculated for each animal during each session.

Pavlovian training involved eight daily sessions during which the levers were retracted. Each session was of $60 \mathrm{~min}$ duration and consisted of presenting two conditioned stimuli (CS1 and CS2; noise, clicker, or tone), each paired with one or another food outcome (O1 and $\mathrm{O} 2$; chocolate and vanilla pellets). One half of mice received CS1-O1 and CS2-O2 pairing and the other half received $\mathrm{CS} 1-\mathrm{O} 2$ and CS2-O1 pairing. Each CS lasted $2 \mathrm{~min}$ in duration and was presented 4 times in a pseudorandom order with a variable intertrial interval of $5 \mathrm{~min}$. $\mathrm{O} 1$ or $\mathrm{O} 2$ was delivered on a random-time $30 \mathrm{~s}$ schedule throughout the appropriate CS. Conditioned responding (CR) was analyzed using an elevation ratio of magazine entries. This ratio was obtained by dividing the total number of magazine entries during CS1 and CS2 by the addition of that number with the total number of magazine entries in the pre-CSs period [i.e., $\mathrm{CS} /(\mathrm{CS}+$ pre-CS $)]$. A pre-CS period was defined for each CS presentation as the 2 min preceding that presentation. One elevation ratio per animal was calculated on each training day. An elevation ratio of 0.5 indicated that the animals entered the magazine as much during the CSs as outside of the CSs (i.e., poor learning). In contrast, an elevation ratio close to 1 showed that the animal entered the magazine substantially more in the presence of the CSs than in their absence (i.e., good learning). The CR for each animal was defined as the average elevation ratio displayed across the last $3 \mathrm{~d}$ of PIT.

Finally, during the test, no outcomes were delivered. Responding was extinguished on both levers for $8 \mathrm{~min}$ to establish a low rate of baseline performance. Each CS was presented four times over the next $40 \mathrm{~min}$ in the following order: CS2-CS1-CS1-CS2-CS1-CS2-CS2-CS1. Stimulus presentations lasted $2 \mathrm{~min}$ and were separated by a 3 min fixed interval. Conditioning during the test was evaluated as lever press rate minus baseline when the stimulus predicted the same outcome as the response (Same), and when the CS predicted a different outcome from the response (Different). The transfer score was calculated as follows: $\frac{\left(\text { Rate }_{\text {same }}-\text { Rate }_{\text {different }}\right)}{\text { Rate }_{\text {baseline }}}$.

\section{Data analysis and statistics}

Curve fitting and data analyses were done with Igor Pro 6.0 (Wavemetrics) and GraphPad Prism 6. Histogram and box plots were used for graphic representation. On the histograms, mean with SEM are shown. On the box plot, the central line represents the median, the edges represent the interquartile ranges, and the whiskers represent the overall distribution. The D'Agostino-Pearson omnibus normality test was used to determine whether sample data had been drawn from a Gaussian distribution. Pairwise comparisons were performed on normal distribution using unpaired or paired $t$ test, as appropriate; non-normal distributions were analyzed by a the Mann-Whitney $U$ test. Some data were also analyzed by a one-way repeated-measures ANOVA followed by a Dunnett's post hoc test or by a two-way repeated-measures ANOVA followed by a Sidak's multiple-comparison post hoc assessment, depending on the experimental design. Correlations were examined by a Spearman rank correlation test. Values are expressed as mean \pm SEM. The level of significance was established as follows: ${ }^{\star} p<0.05,{ }^{* *} p<0.01$, and ${ }^{* * *} p<0.001$.

\section{Results}

\section{Inactivation of NMDA-R in striatopallidal neurons and} functional validation of the transgenic model

NMDA-Rs are heterotetramers that require two essential GluN1 subunits for their formation and functionality (Monyer, 1992). The Grin $1^{\text {lox/lox }}$ mouse model carries two LoxP sequences flanking the exons 9 and 10 of Grin1, the gene encoding the GluN1 subunit (Dang et al., 2006). To obtain specific ablation of Grin1 in iMSNs, these mice were crossed with Adora2a-Cre $\left(\mathrm{A}_{2 \mathrm{~A}} \mathrm{Cre}^{+/-}\right)$ mice (Durieux et al., 2009; Durieux et al., 2012) expressing Cre recombinase selectively in iMSNs. Subsequently, to identify cells lacking GluN1, the $\mathrm{A}_{2 \mathrm{~A}} \mathrm{Cre}^{+/-}$Grin $1^{\text {lox/lox }}$ mice were crossed with the Rosa26-LSL-YFP reporter line (Srinivas et al., 2001), allowing specific expression of YFP in the striatopallidal neurons and resulting in $\mathrm{A}_{2 \mathrm{~A}} \mathrm{Cre}^{-/+} \mathrm{Grin} 1{ }^{\text {lox/lox }}$ Rosa26-YFP (cKO) mice.

We first validated the specificity and efficiency of NMDA-R deletion using immunofluorescence, FACS, and reverse transcription qRT-PCR analyses. YFP was highly expressed within the striatum and the GPe, the target nucleus of striatopallidal neurons (Fig. $1 A, B$ ). No YFP staining was detected in the $\mathrm{SNr}$, the target nucleus of the striatonigral neurons. Therefore, YFP expression appears to be restricted to the indirect pathway. Some scattered positive neurons were also found in the piriform cortex, the dentate gyrus of the hippocampus, and in the vestibular nucleus, as described previously (Durieux et al., 2009). Those structures, containing only few $\mathrm{YFP}^{+}$cells, do not project directly onto striatopallidal neurons (Wall et al., 2013); therefore, the basal ganglia related behavior is not likely to be influenced by this limited number of neurons. This indicates that the highest den- 

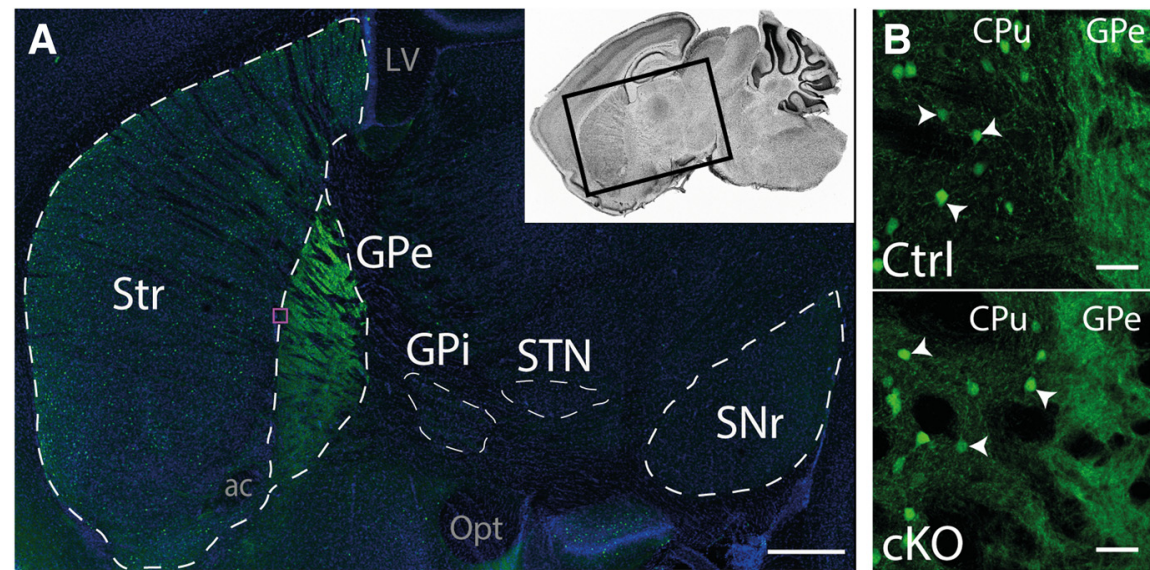

$\mathbf{F}$

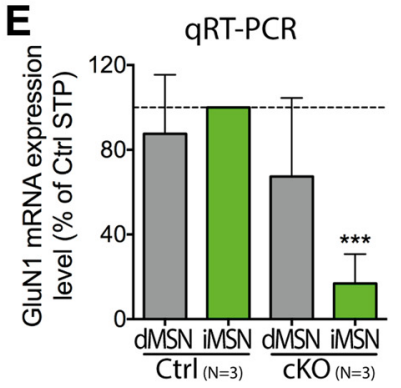

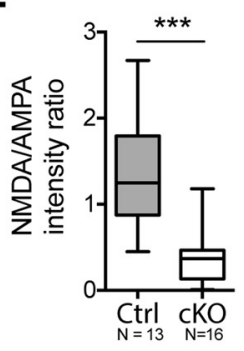
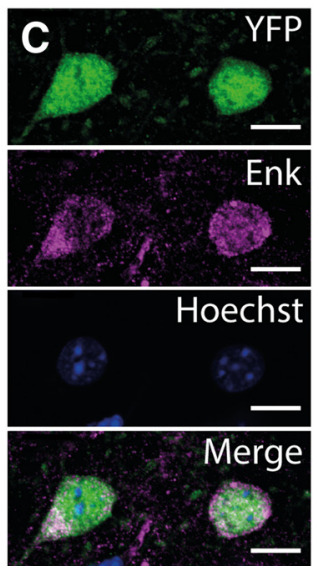

G

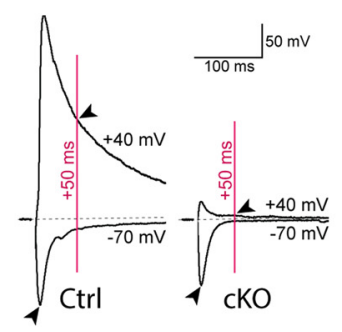

Figure 1. Confocal images, cell sorting coupled to qRT-PCR analysis, and voltage-clamp recordings of cK0 and Ctrl (A $A_{2 A} C^{-1+}{ }^{-1+}$ Rosa26-YFP) mouse brain slices showing the specificity and efficiency of striatopallidal inactivation of GluN1. $A$, Single YFP immunostaining of parasagittal tilted $\left(10^{\circ}\right)$ brain slice section showing the specific labeling of the striatum (Str) and the GPe, whereas the internal part of the globus pallidus (GPi), the subthalamic nucleus (STN), and the SNr are unstained. Targeted zone for $\boldsymbol{B}$ is shown with a red square. LV, Lateral ventricle; ac, anterior commissure; Opt, Optic tract. Scale bar, $500 \mu \mathrm{m}$. B, YFP immunostaining showing labeled somata (arrowheads) only located in the caudate putamen (CPu), whereas GPe contains labeled nerve fibers. Scale bar, $40 \mu \mathrm{m}$. C, Double immunostainings showing colocalization between YFP and enkephalin (Enk). Scale bars, $10 \mu \mathrm{m} . D$, Examples of FACS purification of YFP neurons. Only the viable cells (Hoechst ${ }^{-}$) were selected. Among those cells, the YFP ${ }^{+} /$Hoechst $^{-}$corresponding to striatopallidal neurons (STP) and the YFP ${ }^{-} /$Hoechst $^{-}$neurons, mostly composed of striatonigral neurons (STN) are

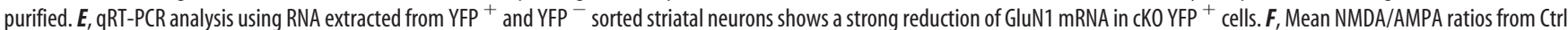
and cKO mice. G, Representative average evoked eEPSCs from control and cKO mice recorded at membrane potential $-70 \mathrm{mV}$ and $+40 \mathrm{mV}$. Scale bar, $50 \mathrm{mV}$ or $50 \mathrm{~ms}$.

sity of YFP expression, that due to $\mathrm{A}_{2 \mathrm{~A}}$ Cre expression, is localized in the striatum. Double-immunofluorescence labeling of YFP and enkephalin, a specific marker for striatopallidal neurons, confirmed selective Cre expression in striatopallidal neurons (Fig. 1C), as described previously (Durieux et al., 2009; Durieux et al., 2012; Ena et al., 2013). Finally, qRT-PCR was performed on cKO and on $\mathrm{A}_{2 \mathrm{~A}} \mathrm{cre}^{-/+}$Rosa26-YFP control mice. Our analysis showed that FACS-purified $\mathrm{YFP}^{+}$cells of cKO mice (Fig. 1D) displayed a significant reduction in mRNA of the GluN1 subunit $\left(n=3\right.$; Mean $_{\text {ско sтр }}$ : $16.81 \pm 13.88 \%$; Wilcoxon signed-rank test, $p<0.0001$; Fig. $1 E)$.

To characterize the functional consequences of GluN1specific deletion on basal synaptic transmission, we performed whole-cell patch-clamp recordings on acute striatal slices in combination with cortical input stimulation within the corpus callosum (Fig. 1G,H). The ratio between AMPA-R- and NMDA-Rmediated currents was obtained by recording eEPSCs in voltage clamp at $-70 \mathrm{mV}$ and $+40 \mathrm{mV}$ (Fig. $1 \mathrm{~K}$ ). As expected, the NMDA/AMPA ratio showed a dramatic decrease in the $\mathrm{YFP}^{+}$ cells of cKO animals $\left(n_{\mathrm{Ctrl}}=13, n_{\mathrm{cKO}}=16 ; 1.40 \pm 0.19 \mathrm{pA}\right.$ vs $0.38 \pm 0.30$ pA; Mann-Whitney test, $p<0.0001$; Fig. $1 F)$, demonstrating that the reduction in GluN1 subunit expression leads to a functional decrease of NMDA signaling. Next, we investigated the cellular consequences of the functional decrease of NMDA signaling in iMSNs.
Striatopallidal neurons lacking NMDA-R have a decreased dendritic arborization, spine density, and spontaneous excitatory synaptic currents

Previous reports have demonstrated that inactivation of GluN1 in both MSN populations altered their morphology (Beutler et al., 2011b). We performed a detailed morphological study of iM$\mathrm{SNs}$ in $\mathrm{cKO}$ and control mice (Fig. 2A). The dendritic morphological characteristics of iMSNs were first quantified by 3D Sholl analysis (Sholl, 1953), which counts intersections between the dendritic tree and imaginary spheres of increasing radius centered on the soma. By reporting the number of intersections as a function of the distance from the soma, this method showed that iMSNs of cKO mice have significantly less dendritic arborization $\left(n_{\mathrm{Ctrl}}=15, n_{\mathrm{cKO}}=14\right.$; two-way ANOVA, $p=0.0004$; Fig. $\left.2 B\right)$. We also plotted the number and the length of dendritic branches against a hierarchy branch order. This analysis demonstrated that reduced dendritic arborization can be explained by a smaller number of dendritic segments $\left(n_{\mathrm{Ctrl}}=10, n_{\mathrm{cKO}}=11\right.$; two-way ANOVA, $p=0.0013$; Sidak's multiple-comparisons test, $p 1 s t=$ $0.2078, p 2 n d=0.0830, p 3 r d=0.0479, p 4 t h<0.0001$; Fig. $2 C$ ) rather than a reduction in dendritic length per branch order (two-way ANOVA, $p=0.2473$; Fig. $2 D$ ). Moreover, using wholecell current-clamp recordings, we observed a smaller membrane capacitance $\left(n_{\mathrm{Ctrl}}=10, n_{\mathrm{cKO}}=12 ; 58.94 \pm 6.46 \mathrm{pF}\right.$ vs $31.71 \pm$ 5.17, unpaired $t$ test, $p=0.0033$; Fig. $2 E$ ), indicating that iMSNs 
A

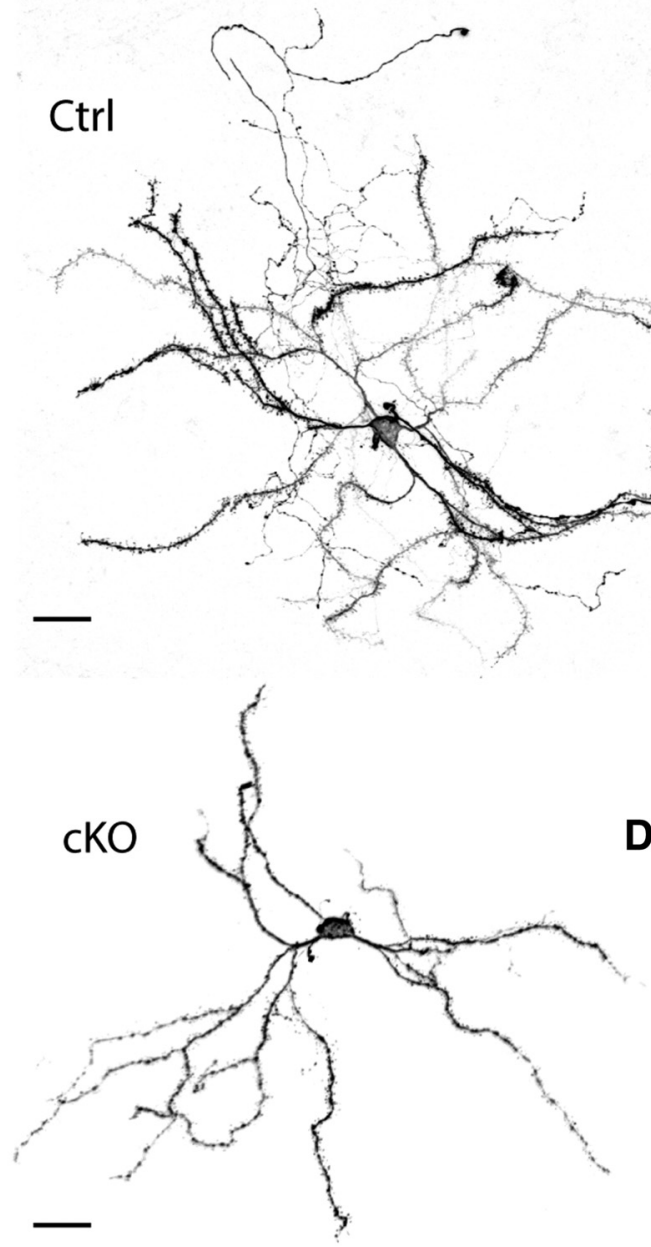

B

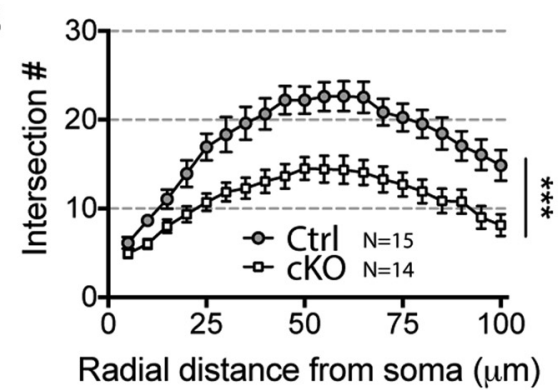

C

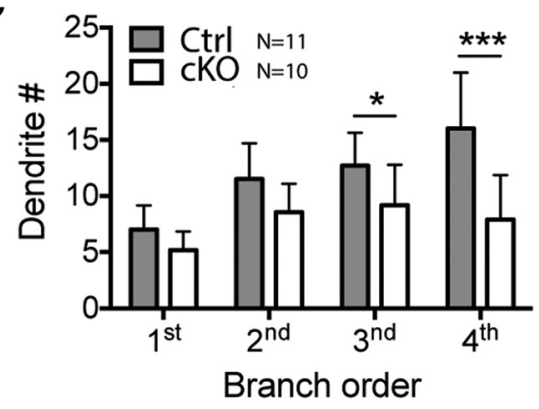

Figure 2. NMDA-R-deficient iMSNs are smaller due to reduced dendritic arborization. $\boldsymbol{A}$, Representative maximal intensity projections of deconvoluted Z-stack obtained from biocytin-filled control (Ctrl) and cKO iMSNs. Scale bar, $20 \mu \mathrm{m}$. B, 3D Sholl analysis of reconstructed neurons showed a reduced dendritic arborization for cKO mice. $\boldsymbol{C}$, Dendrite number in function of branch order is reduced in cKO iMSNs. $\boldsymbol{D}$, Dendritic branch length in function of dendrite order is not different between the two groups. $\boldsymbol{E}$, Whole-cell current-clamp recordings showed a smaller membrane capacitance for cKO iMSNs, indicating a smaller surface area.

in $\mathrm{cKO}$ mice had a smaller membrane surface, which confirms morphological measurements of dendritic arborization.

In the striatum, dopaminergic terminals from $\mathrm{SNc}$ and glutamatergic cortical afferents converge onto the dendritic spines of MSN (Reynolds and Wickens, 2002), forming essential sites of information processing (Surmeier et al., 2007; Gardoni et al., 2010). Therefore, further quantifications were performed on the biocytin-filled dendritic endings in control and cKO neurons, followed by $3 \mathrm{D}$ reconstruction of higher-resolution image sets (Fig. 3A). Spine density was significantly lower in cKO striatopallidal neurons than in controls $\left(n_{\mathrm{Ctrl}}=18, n_{\mathrm{cKO}}=15 ; 1.463 \pm\right.$ $0.119 \mu \mathrm{m}^{-1}$ vs $1.041 \pm 0.0902 \mu \mathrm{m}^{-1}$; unpaired $t$ test, $p=0.0109$; Fig. $3 B$ ). Spines that undergo subtle structural rearrangements, including changes in length and width, are proposed to reflect differences in synaptic potentiation processes. Spine length in cKO striatopallidal neurons was comparable to that of controls $(1.427 \pm 0.128 \mu \mathrm{m}$ vs $1.519 \pm 0.128 \mu \mathrm{m}$; Mann-Whitney test, $p=0.4581$; Fig. $3 C$ ), whereas the spine volume in cKO neurons was considerably smaller than that in controls $\left(n_{\mathrm{Ctrl}}=6, n_{\mathrm{cKO}}=\right.$ $6 ; 140.1 \pm 7.72 \mathrm{~nm}^{3}$ vs $94.93 \pm 13.28 \mathrm{~nm}^{3}$; Mann-Whitney test, $p=0.0152$; Fig. $3 D$ ). This difference was due to a decrease of spine head volume in iMSN of cKO mice $\left(84.07 \pm 7.70 \mathrm{~nm}^{3}\right.$ vs
$54.46 \pm 9.33 \mathrm{~nm}^{3}$; Mann-Whitney test, $p=0.0411$; Fig. $\left.3 E\right)$. Interestingly, reconstructions also revealed that the mean dendrite diameter of cKO neurons was reduced compared with controls $\left(n_{\mathrm{Ctrl}}=17, n_{\mathrm{cKO}}=14 ; 0.805 \pm 0.053 \mu \mathrm{m}\right.$ vs $0.567 \pm 0.051$ $\mu \mathrm{m}$; unpaired $t$ test, $p=0.0221)$.

We also performed a functional assessment of the glutamatemediated spontaneous synaptic activity onto cKO striatopallidal neurons by recording sEPSCs (Fig. $4 A$ ). The distribution plot of sEPSC amplitudes was shifted leftward in cKO neurons (Fig. $4 B$ ) as the sEPSC amplitudes were decreased $\left(n_{\mathrm{Ctrl}}=13, n_{\mathrm{cKO}}=12\right.$; $13.93 \pm 1.538 \mathrm{pA}$ vs $9.155 \pm 0.7718 \mathrm{pA}$; unpaired $t$ test, $p=$ 0.0217; Fig. 4C). However, the kinetic parameters of those currents were not modified (rise slope: $2.766 \pm 0.217 \mathrm{pA} / \mathrm{ms}$ vs $2.899 \pm 0.1827 \mathrm{pA} / \mathrm{ms}$; unpaired $t$ test, $p=0.5594$; decay slope: $-10.45 \pm 1.058 \mathrm{pA} / \mathrm{ms}$ vs $-12.03 \pm 0.8971 \mathrm{pA} / \mathrm{ms}$; unpaired $t$ test, $p=0.5767$; Fig. $4 E$ ), suggesting that there was no subunit change. In addition, the sEPSC frequency was also reduced in cKO neurons $(1.942 \pm 0.1903 \mathrm{pA}$ vs $0.9019 \pm 0.1187 \mathrm{pA}$; unpaired $t$ test, $p<0.0001$; Fig. $4 F)$. This frequency is thought to reflect the probability of vesicle release from the presynaptic terminal and the number of release sites. Further, because most 

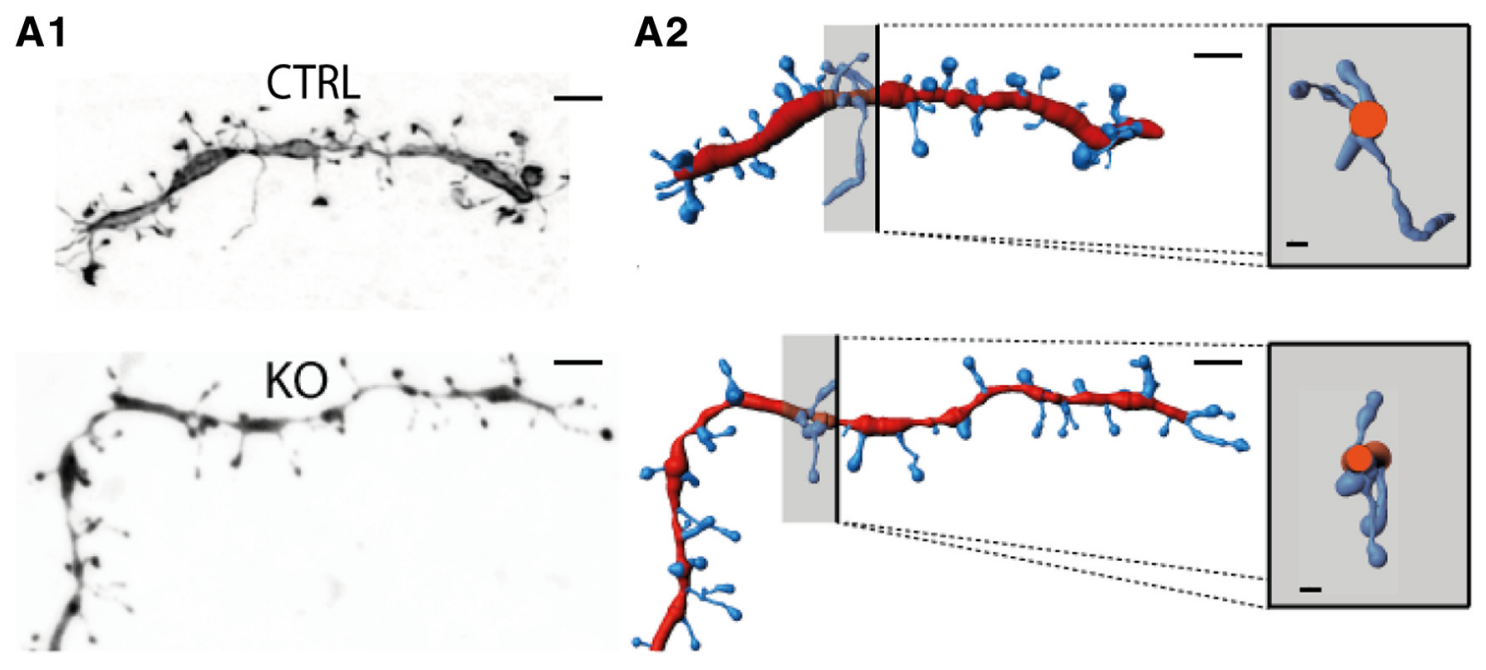

B

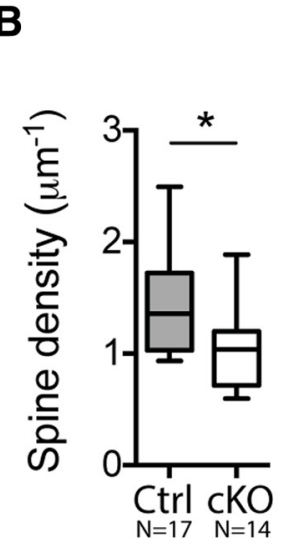

C

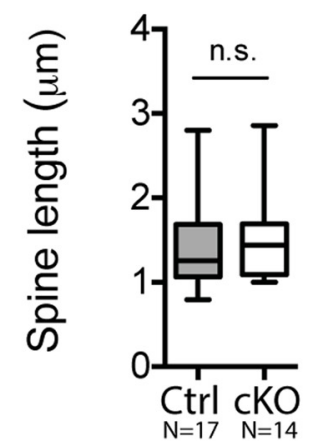

D

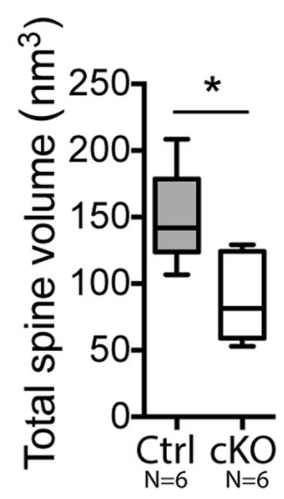

E

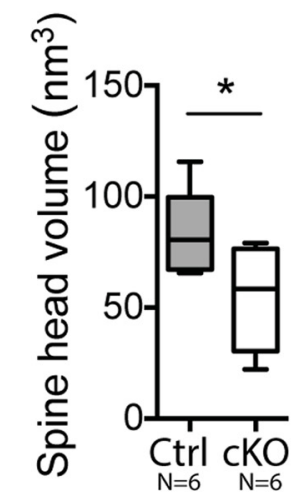

Figure 3. NMDA-R-deficient iMSNs have reduced spine density and dendrite diameter. $\boldsymbol{A}, 3 \mathrm{D}$ morphological analysis of iMSNs in Control (Ctrl) and cKO mice. $\boldsymbol{A}$ 1, Representative maximal intensity projections of deconvoluted Z-stack obtained from biocytin-filled Ctrl and cKO iMSNs. Scale bar, $2 \mu \mathrm{m}$. A2, Microvolumetric reconstructions of terminal dendrites (red) and spines (blue) using Imaris Filament. Insert scale bar, $0.4 \mu \mathrm{m}$. Right, Dendritic section of dendrite endings from the section plan indicated in black. $\boldsymbol{B}$, Mean spine density in dendrite endings is reduced in cKO mice. $\boldsymbol{C}$, No difference in spine lengths was observed between the two groups. $\boldsymbol{D}, \boldsymbol{E}$, Spine volume of cK0 cells $(\boldsymbol{D})$ is reduced due to a reduced spine head volume $(\boldsymbol{E})$.

central synapses contain only one release site each, frequency may reflect the number of spines (Kerchner and Nicoll, 2008). The sEPSC amplitude corresponds to the glutamate sensitivity at the postsynaptic membrane, which in turn reflects the number and conductance of its glutamate receptors (Kerchner and Nicoll, 2008). Therefore, in our cKO model, the reduction in sEPSC frequency could be explained by reduced spine density, whereas decreased sEPSC amplitude could be explained by a reduction in the number or conductance of receptors.

To investigate the potential alteration of AMPA-R number or conductance, we applied peak-scaled NSFA to sEPSC recordings. For each cell, a parabolic variance versus mean current curve was obtained (see individual samples in Fig. 4G,H). The calculated number of open channels was significantly lower in iMSNs from cKO mice $\left({ }_{n \text { Ctr }} \mathrm{l}=6, \mathrm{n}_{\text {сKO }}=6 ; 20.08 \pm 2.24\right.$ vs $12.29 \pm 1.51$ Mann-Whitney test, $p=0.0260$; Fig. $4 I)$. However, unitary currents were not significantly different $(0.77 \pm 0.09 \mathrm{pA}$ and $0.79 \pm 0.08 \mathrm{pA}$; Mann-Whitney test, $p=0.6753)$. Therefore, it follows that the reduction in sEPSC amplitude induced by the deletion of NMDA-R could be attributed to a decrease in the number of opened receptor channels instead of a change in unitary currents.

The significant reduction in cortical excitatory inputs to cKO striatopallidal neurons could be partially compensated by a balanced reduction in auto-inhibitory feedback or other inhibitory inputs to the iMSN. In other words, a reduction in inhibitory feedback may occur as a mechanism of homeostatic plasticity in the context of chronically reduced excitatory input. To test this possibility, sIPSCs in iMSNs were recorded with a high-chloride $\mathrm{Cs}^{+}$-based intracellular solution. In addition, the membrane potential was held at $-70 \mathrm{mV}$ in the presence of CNQX $(10 \mu \mathrm{M})$ to block glutamatergic receptors. The inward $\mathrm{GABA}_{\mathrm{A}}$-mediated currents recorded did not differ between $\mathrm{CKO}$ and control mice in terms of frequency $\left(n_{\mathrm{Ctrl}}=8, n_{\mathrm{cKO}}=10 ; 1.07 \pm 0.25 \mathrm{~Hz}\right.$ vs $1.35 \pm$ $0.28 \mathrm{~Hz}$; Mann-Whitney test, $p=0.6498$ ) or amplitude (36.37 \pm 7.45 pA vs $35.92 \pm 7.42$ pA; Mann-Whitney test, $p=0.9156)$. In fact, the recording of sEPSCs and sIPSCs showed a shift in the ratio of excitation to inhibition in favor of inhibition in iMSNs in the $\mathrm{cKO}$ mice. These results show that the deletion of the NMDA-R in iMSNs only leads to a reduction in excitatory drive.

\section{Removing NMDA-R from striatopallidal neurons induced homeostatic changes in intrinsic excitability}

Patch-clamp recordings were performed in current-clamp configuration to investigate the electroresponsiveness of striatopallidal neurons. By measuring the voltage response to intrasomatic injection of depolarizing currents of increasing intensities, we first evaluated the active cell membrane properties (Fig. $5 \mathrm{~A}$ ). The rheobase current was significantly smaller in cKO neurons $\left(n_{\mathrm{Ctrl}}=17, n_{\mathrm{cKO}}=13 ; 67.65 \pm 4.03 \mathrm{pA}\right.$ vs $29.54 \pm 3.58 \mathrm{pA}$; 
A

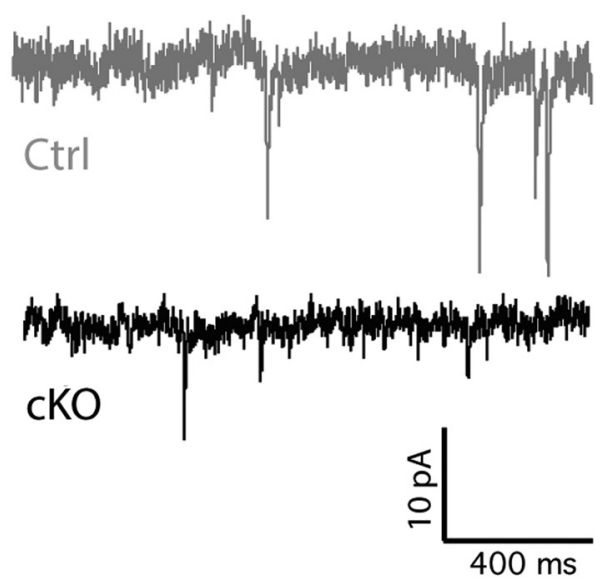

C

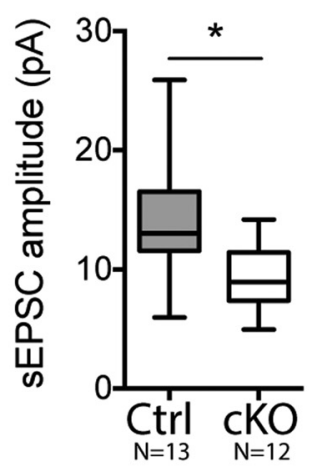

D

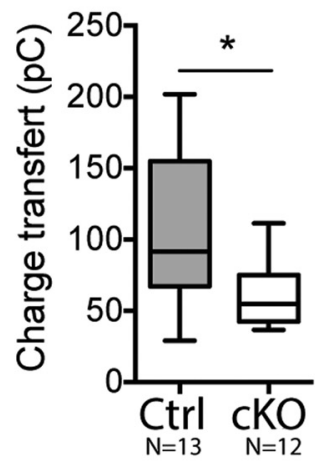

B

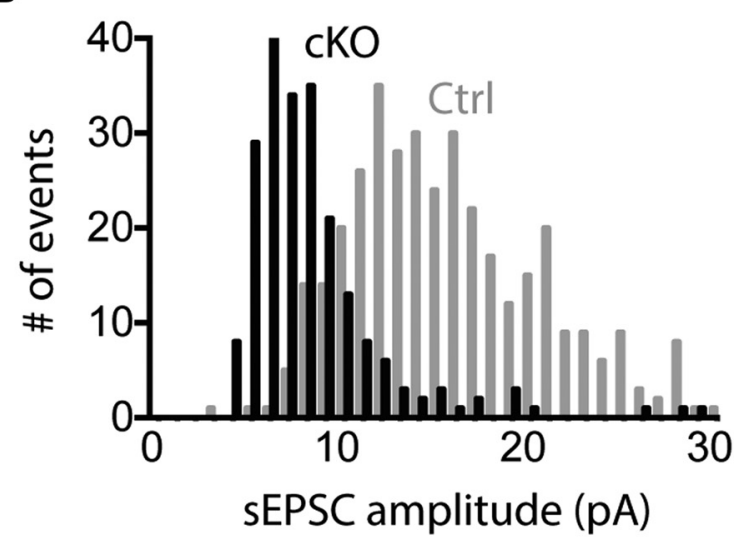

E

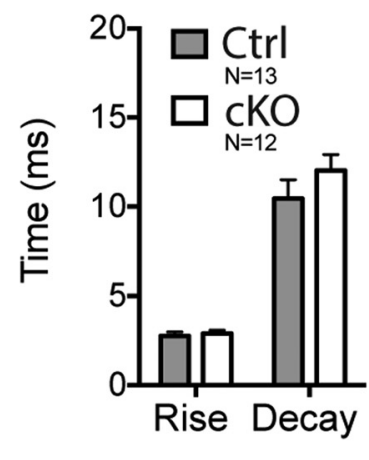

F

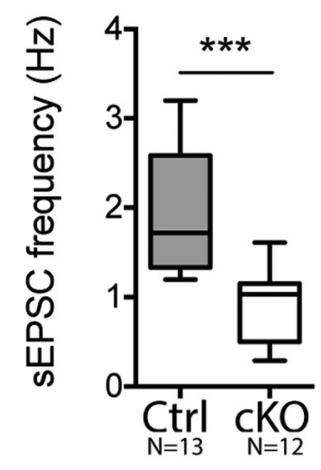

I

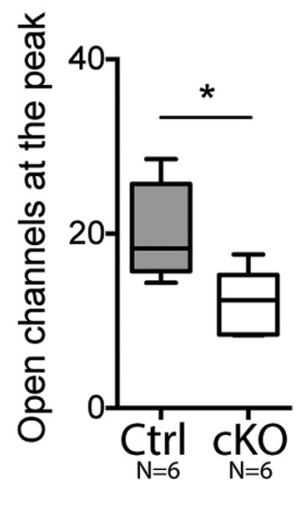

Figure 4. Spontaneous EPSCs are decreased in NMDA-R-deficient iMSNs. $A$, Representative current traces of sEPSCs recorded from control and cKO mice. $\boldsymbol{B}$, Distribution of sEPSC amplitudes in a cKO and a control cell showing a significant shift to the left for the cKO neuron. $\boldsymbol{C}, \boldsymbol{D}$, Summary graph showing a decrease of sEPSC amplitude in $\mathrm{K}$ O mice $(\boldsymbol{C})$, leading to a reduced charge transfer (D). $\boldsymbol{E}$, There was no difference in kinetic parameters for either the rise slope or the decay slope. $\boldsymbol{F}$, SEPSC frequency was decreased in cKO animals. $\boldsymbol{G}, \boldsymbol{H}$, Peak-scaled nonstationary fluctuation analysis was performed on sEPSC recordings and analysis of representative control and cKO cells is presented. The slope represents the unitary channel current. $I$, Estimated number of AMPA-R open at the peak is lower in cKO cells.

unpaired $t$ test, $p<0.0001$; Fig. $5 B)$. The difference in rheobase was not due to a difference in spike threshold $(-47.36 \pm 2.339$ $\mathrm{mV}$ vs $-48.56 \pm 4.163 \mathrm{mV}$; unpaired $t$ test, $p=0.8354)$, which is in agreement with previously reported values (Cepeda et al., 2008). However, the reduced rheobase value can be explained by the observed increase in the cKO cell input resistance $\left(n_{\mathrm{Ctrl}}=12\right.$, $n_{\mathrm{cKO}}=14 ; 274.2 \pm 40.67 \mathrm{M} \Omega$ vs $677.1 \pm 91.56 \mathrm{M} \Omega$, MannWhitney test, $p<0.0001)$. The mean value of input resistance of the control cells is similar to those reported previously (Azdad et al., 2009; Marty and Spigelman, 2012). In addition, there was a decrease in latency for first APs during current injection in $\mathrm{cKO}$ neurons $\left(n_{\mathrm{Ctrl}}=17, n_{\mathrm{cKO}}=13 ; 710.0 \pm 39.09 \mathrm{~ms}\right.$ vs $375.9 \pm$ $54.04 \mathrm{~ms}$; unpaired $t$ test, $p<0.0001$; Fig. $5 C$ ). The relationship between spike frequencies and injected current from the rheobase was determined at a basal membrane potential of $-80 \mathrm{mV}$ and used to construct current-frequency plots (Fig. 5D). At low current intensities, the current-frequency plots were interpolated with a straight line and the slope of this line permitted us to evaluate the intrinsic excitability. We observed that the slope of the current frequency plot was steeper for cKO cells $\left(n_{\mathrm{Ctrl}}=14\right.$, 
A

$+40 \mathrm{pA}$

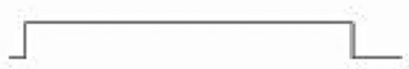

Ctrl
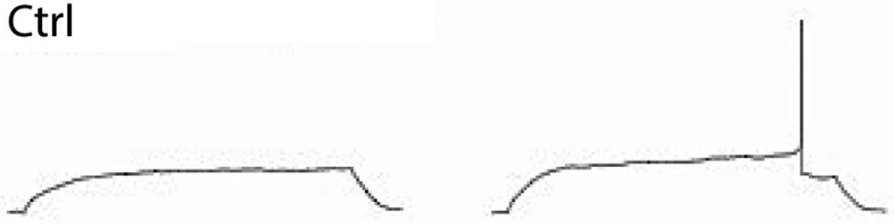

cKO
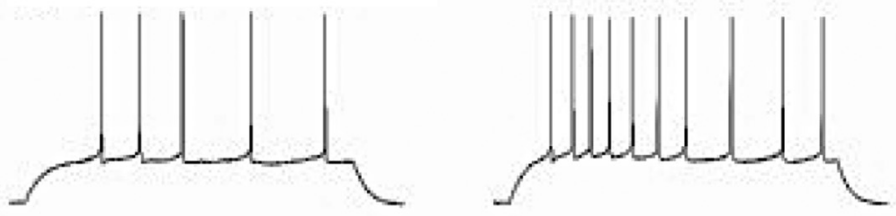
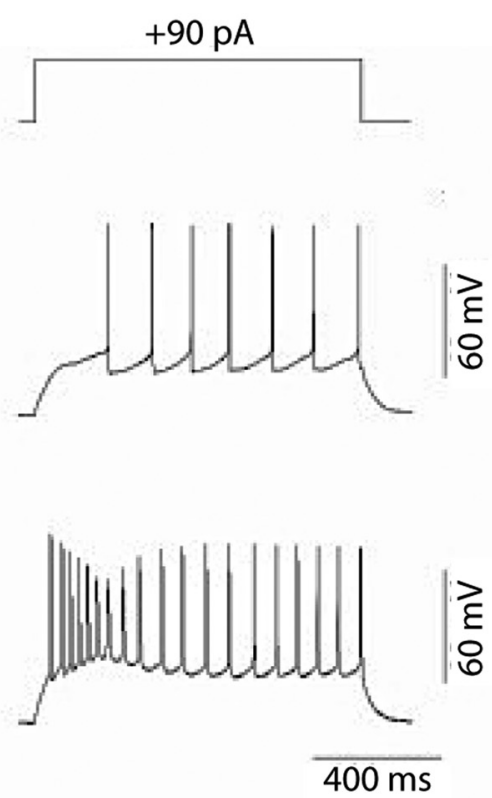

B

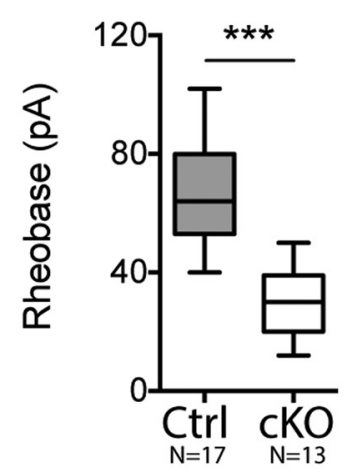

C

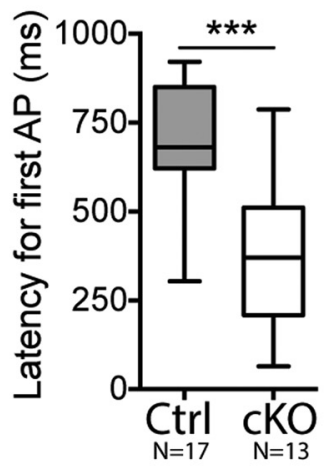

D

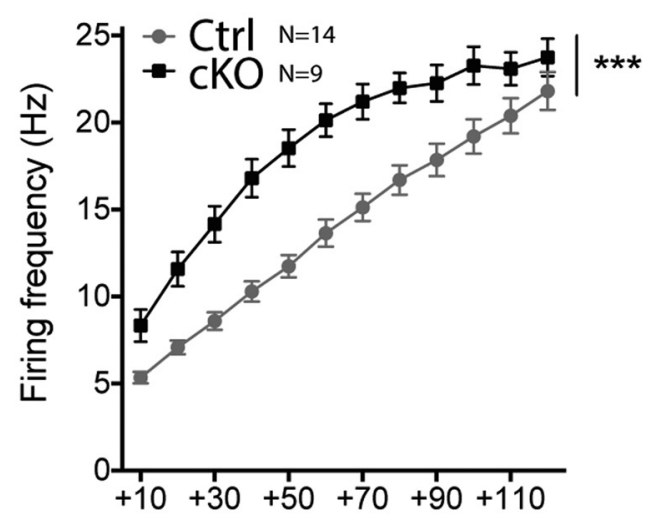

Injected current from rheobase (pA)
E

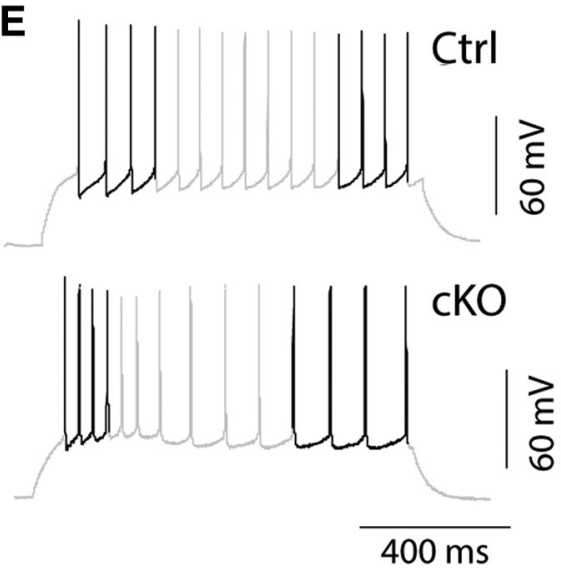

$\mathbf{F}$

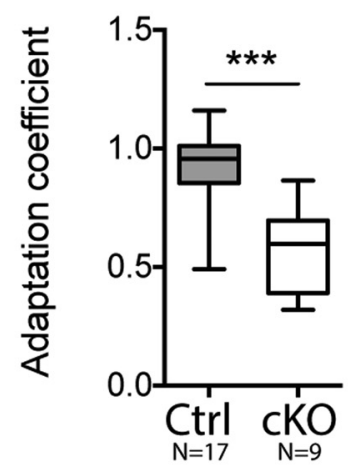

G

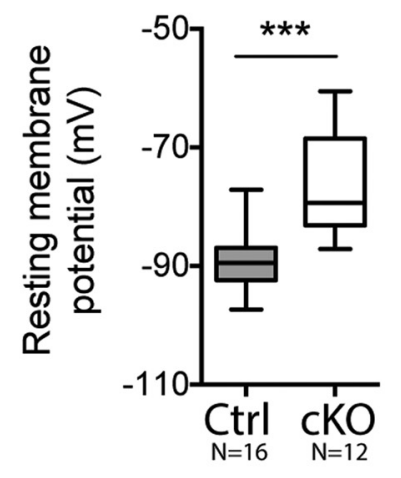

Figure 5. NMDA-R-deficient iMSNs show altered excitability. $A$, Traces resulting from 40,50, and $90 \mathrm{pA}$ current injections are shown for representative striatopallidal neurons in control $(\mathbf{C t r l})$ and $\mathrm{CKO}$ animals. $\boldsymbol{B}, \boldsymbol{C}$, Rheobase is smaller for cKO neurons $(\boldsymbol{B})$ and latency for first APs during current injection is decreased in cKO neurons (C).D, Spiking frequency as a function of injected current (10 pA increment) plots. Firing frequency is overall higher in $\mathrm{K} O$ animals. $\boldsymbol{E}$, Representative traces from cKO and Ctrl striatopallidal neuron resulting from current injection inducing a firing rate close to $15 \mathrm{~Hz}$ (gray). The three first and three last ISIs are shown in black. $\boldsymbol{F}$, Comparison between the three first and three last ISIs within the same trace shows a higher adaptation of cKO neurons. $\mathbf{G}$, Resting membrane potential is significantly more depolarized in cKO neurons. 
$n_{\mathrm{cKO}}=9 ; 1.312 \pm 0.1188 \mathrm{~Hz} \cdot \mathrm{pA}^{-1}$ vs $3.301 \pm 0.2497 \mathrm{~Hz} \cdot \mathrm{pA}^{-1}$, $p=0.0079)$, indicating that the excitability of cKO cells was increased even after adjustments for the rheobase. At low frequencies, APs of control cells occurred in regular trains. However, a moderate spike frequency adaptation is usually observed. In contrast, $\mathrm{CKO}$ cells showed strong firing adaptation even at low firing rates. To quantify the extent of spiking adaptation, we computed the ratio of the ISIs measured within the four first and the four last APs of the current step injection, inducing a $15 \mathrm{~Hz}$ average firing rate (Fig. $5 E$ ). The adaptation coefficient of $\mathrm{cKO}$ cells was lower $(0.91 \pm 0.04$ vs $0.56 \pm 0.06$; Mann-Whitney test, $p=0.0003$; Fig. $5 F$ ), showing a higher adaptation. Finally, the resting membrane potential in cKO cells was more depolarized than in control cells $\left(n_{\mathrm{Ctrl}}=16, n_{\mathrm{cKO}}=12 ;-89.60 \pm 1.234 \mathrm{mV}\right.$ vs $-76.79 \pm 2.51 \mathrm{mV}$, unpaired $t$ test, $p=0.0003$; Fig. $5 G)$. In conclusion, we showed that reduced cortical drive to iMSNs is partially balanced in cKO mice by an augmentation in cellular excitability.

\section{NMDA-R is required in memory processes involved in habituation}

Given that structural elements that mediate both chemical and structural synaptic plasticity regulate the connectivity of the cortex to the striatum and that the changes in spine density as well as in sEPSC frequency and amplitude positively correlate with cognitive performance, these changes might likely contribute to change in behaviors of these $\mathrm{cKO}$ mice.

We have demonstrated previously the involvement of striatopallidal neurons in locomotor and exploratory behaviors (Durieux et al., 2009; Durieux et al., 2012). Therefore, here, we first evaluated the consequences of GluN1 deletion in iMSNs on those behaviors by comparing $\mathrm{cKO}$ and $\mathrm{A}_{2 \mathrm{~A}} \mathrm{cre}^{-/-}$Grin ${ }^{\text {lox/lox }}$ Rosa26YFP control littermates in an open-field task for 3 consecutive days. There were no differences in exploratory behavior on the first day between control and cKO mice $\left(n_{\mathrm{Ctrl}}=21, n_{\mathrm{cKO}}=25\right.$; Sidak's multiple-comparisons test, $p>0.05$; Fig. $6 A$ ). In control mice, repeated exposure to the same environment across 3 consecutive days induced habituation, as expected (Thompson and Spencer, 1966). A significant difference was detected in openfield habituation over time (two-way ANOVA, $p=0.0027$; Fig. $6 A$ ) between the $\mathrm{CKO}$ and control mice, with $\mathrm{CKO}$ mice showing greater locomotor activity on day 3 (Sidak's multiplecomparisons test, $p<0.001)$. To further assess alterations in habituation behavior, both groups were tested in a spontaneous object recognition task. In this task, mice are introduced to an open field with two similar objects placed inside and allowed to explore the objects (Le Merrer et al., 2013). In the initial trial, with the novel objects, control and cKO mice did not exhibit any difference in object exploration measured by the number of interactions with both objects $\left(n_{\mathrm{Ctrl}}=22, n_{\mathrm{cKO}}=24\right.$; Mann-Whitney test, $p=0.7155)$. In other words, cKO mice did not show any alteration in novelty-induced exploration of the objects, confirming the results obtained in the open-field task. The mice were subsequently returned to the test apparatus, which contained one familiar object that had been presented in the first trial and one novel object. Control mice interacted more with the novel object (ratio paired $t$ test, $p=0.0380$; Fig. $6 B$ ). Conversely, cKO mice did not show any detectable preference in exploration of either object (ratio paired $t$ test, $p=0.2329$; Fig. $6 B$ ). Together, these results suggest that the habituation to novel spaces and objects is mediated by NMDA-R in iMSNs. However, some scattered $\mathrm{YFP}^{+}$neurons were also found in the dentate gyrus of the hippocampus. Because only a few cells displayed YFP staining and
NMDA-R functional deletion was not confirmed in these cells, we suggest that the reduced novel object habituation is likely due to NMDA-R in iMSNs.

To exclude potential confounding factors such as altered levels of anxiety-related behaviors or differences in general locomotor activity, we first performed a light and dark box test, a behavioral task used to study anxiety-related behavior (Bourin and Hascoët, 2003). No significant difference was found between groups for the time spent in either box $\left(n_{\mathrm{Ctrl}}=19, n_{\mathrm{cKO}}=21\right.$; Mann-Whitney test, $p=0.3913$ ). Second, we measured innate anxiety levels by introducing the mice to a brightly lit open field. Here also, no differences were found in this task, assessed by estimating the time spent in the central zone $\left(n_{\mathrm{Ctrl}}=19, n_{\mathrm{cKO}}=\right.$ 27; Mann-Whitney test, $p=0.1666)$. We therefore conclude that cKO mice do not present alterations in anxiety-related behavior. We also investigated general locomotor activity using home cage tracking. Again, we did not find a significant difference between groups in the total horizontal distance traveled $\left(n_{\mathrm{Ctrl}}=22\right.$, $n_{\mathrm{cKO}}=24$; unpaired $t$ test, $\left.p=0.1446\right)$. To further validate the results of decreased habituation found in the $\mathrm{cKO}$ mice during the novel object recognition task, the discriminating abilities of the mice should be functional. We performed an additional experiment, the CPP task. CPP occurs when a subject comes to prefer one place more than an other because the preferred location has been paired previously with a rewarding event. In this paradigm, the rewarding properties of amphetamine were paired with initially neutral visual and tactile cues on the walls of an apparatus compartment (dots or lines) (Durieux et al., 2009). After amphetamine conditioning, both genotypes showed a preference for the amphetamine-paired compartment $\left(n_{\text {Ctrl_sALIN }}=\right.$ $11, n_{\text {Ctrl_AMPHET. }}=11, p_{\text {Ctrl }}<0.0001 ; n_{\text {cKO_SALIN }}=12$, $n_{\text {cKO_AMPHET. }}=12, p_{\text {cKO }}<0.0381$; Fig. $5 C$ ) without genotype differences $\left(n_{\text {Ctrl_AMPHET. }}=11, n_{\text {cKO_AMPHET. }}=12, p=0.6468\right)$. This experiment showed that $\mathrm{CKO}$ mice are able to use and remember visual and tactile cues; therefore, the changes that we observed during the novel object recognition task were not due to deficits in visual or tactile memory, but rather were more likely due to the altered habituation. In addition, our data showed that the iMSN NMDA-R is not implicated in the rewarding effect of amphetamine, whereas previous reports have demonstrated the role of dMSN NMDA-R in the amphetamine-mediating reward effect in CPP (Beutler et al., 2011). Therefore, the NMDA-R of the direct pathway, and not of the indirect pathway, seems to be implicated in the rewarding effect of amphetamine.

Together, our data provide evidence that the deletion of iMSN NMDA-R induces alteration of habituation phenotype in cKO mice. This phenotype occurs independently of their anxietyrelated behavior, general locomotor activity levels, or visual memory.

\section{Striatopallidal NMDA-R deletion alters action selection or fine motor learning}

The striatum also plays a key role in motor learning, enabling the performance of many types of actions from simple movements to more complicated organized behaviors, including multiple distinct actions performed in serial order (Rothwell et al., 2015). Such motor learning is regulated by several synaptic inputs to both MSN pathways. Because previous studies indicated that striatal NMDA-Rs are required in motor learning (Dang et al., 2006; Beutler et al., 2011b; Eldred and Palmiter, 2013), we determined the specific role of iMSN NMDA-Rs in simple motor learning and more complex behavioral acquisition. Previous studies using the accelerating rotarod tasks indicated that striatal NMDA-R is 
A
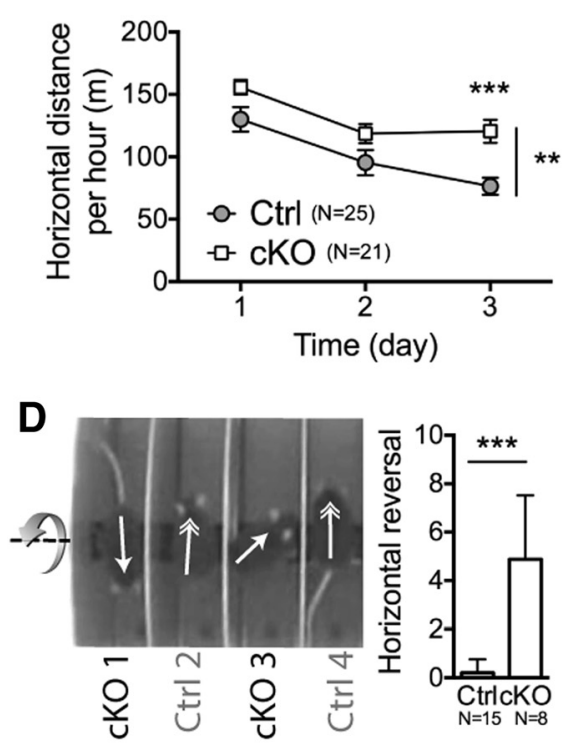

G

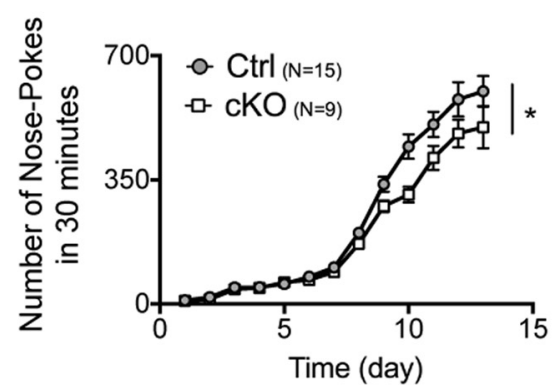

B

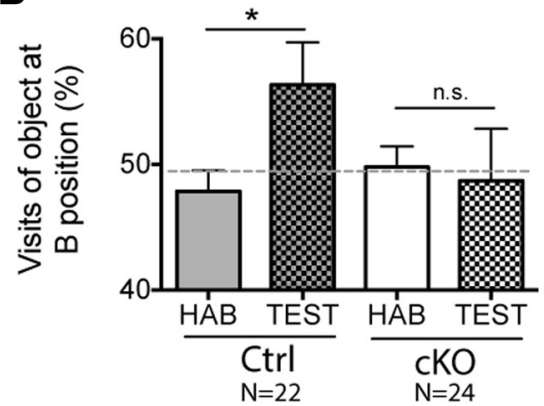

E

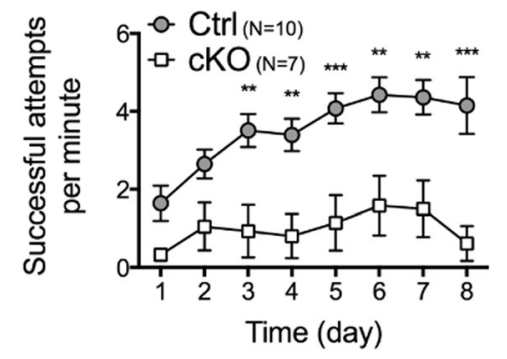

H

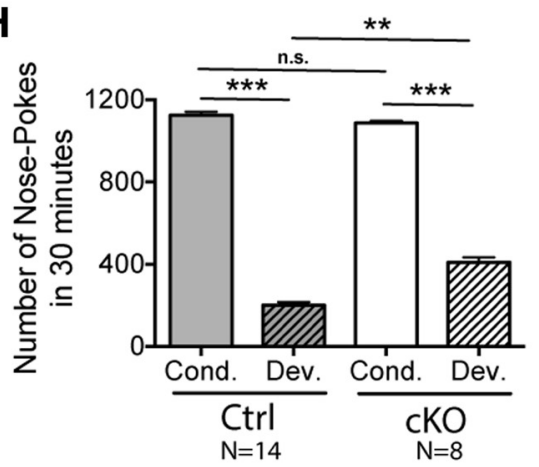

C

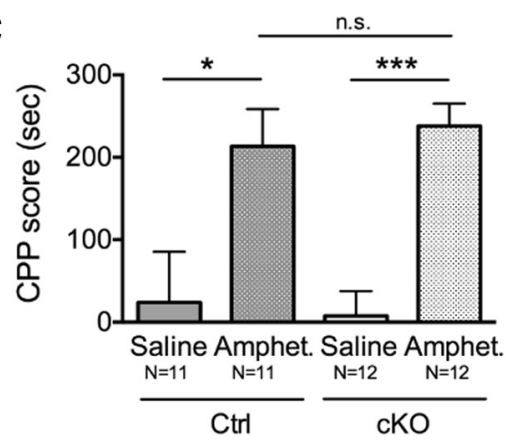

F

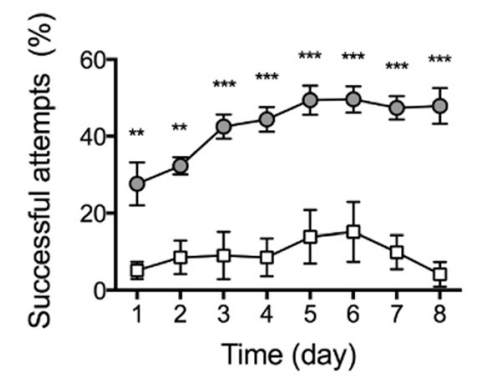

I

Figure 6. Habituation and learning are altered in mice depleted of NMDA-R in iMSNs. A, One hour open-field activity analyzed in cKO and $A_{2 A}{ }_{C r e}{ }^{-1-} G_{\text {Gin }}{ }^{\text {lox/lox }}$ Rosa26-YFP (control, Ctrl) mice shows an increase in the total horizontal distance run by CKO mice at day 3. $B$, Habituation is impaired in cKO mice during the novel object recognition task (HAB, habituation phase; TEST, test phase). $\boldsymbol{C}$, CPP is not altered in cKO mice, confirming that the visual memory of the $\mathrm{KO}$ is functional. $\boldsymbol{D}$, During the accelerating rotarod task, $\mathrm{CKO}$ mice (i.e., cKO 1) reversed horizontally $\left(180^{\circ}\right)$ and continued the walk backwards, in contrast to control mice, which kept the same walk orientation. Arrows indicate the walking orientation of each mouse. The number of horizontal reversals $\left(180^{\circ}\right)$ accomplished by cKO mice is significantly higher than in $\boldsymbol{C}$ trl. $\boldsymbol{E}, \boldsymbol{F}$, The average speed of success $(\boldsymbol{F})$ as well as the average success rates over time from the same group of mice presented in $\boldsymbol{E}$ during the training period of the single-pellet reaching task are significantly higher for the Ctrl mice than for the cKO mice. The cKO mice are not able to learn the task because there is no effect of the time on their speed of success or their rate of success. $G$, Mice were trained in a Skinner box to do an NP to obtain a food pellet with a first period of fixed ratio (starting with 1:1, ending with 10:1) followed by a variable ratio (starting with $\pm 10: 1$, ending with $\pm 20: 1$ ) schedule. Conditioned instrumental reinforcement with a fixed ratio schedule reveals impaired attribution of NP to a reward in cK0 animals during this initial learning phase (days $1-13$ ). $\boldsymbol{H}$, After $25 \mathrm{~d}$ of learning, $\mathrm{CK} 0$ and $(\mathrm{Ctrl}$ mice reached a plateau for $3 \mathrm{~d}$ (Cond.), which was not different between the two groups, whereas, afterward, the devaluation was significantly lower for cK0 mice because the NP level was significantly higher. I, During the PIT, the Ctrl mice exhibited a significantly higher lever press rate when the stimulus predicted the same outcome as the response than when the stimulus predicted a different outcome, whereas cKO mice displayed unspecific lever pressing.

required for motor skill learning (Dang et al., 2006; Beutler et al., 2011b; Eldred and Palmiter, 2013). To evaluate specifically the involvement of iMSN NMDA-R in these behaviors, mice were trained to perform two motor skill learning tasks: an accelerating rotating rod and a run-away test (Bearzatto et al., 2006). Across training sessions, the two genotypes improved their motor performance similarly in the two learning tasks $\left(n_{\mathrm{Ctrl}}=16, n_{\mathrm{cKO}}=9\right.$; Two-way ANOVA, $\left.p_{\text {RunAway }}=0.2636, p_{\text {Rotarod }}=0.1706\right)$. Those results demonstrated that iMSN NMDA-Rs are not required for simple motor learning. Interestingly, during the accelerating rotarod task, cKO mice performed frequent horizontal reversals (Mann-Whitney test, $p<0.0001$; Fig. 6D), which were absent in the control group (see also Movie 1). This result indicates that iMSN NMDA-R deletion may change the process of action selection within the BG. To investigate whether this behavior reflects alterations in action selection, we performed a more sophisticated motor-skill learning paradigm: the single-pellet reaching task (Whishaw et al., 1986; Faraji and Metz, 2007; Sloan et al., 2015). This paradigm requires a precise and coordinated sequence of movements in serial order of the forelimb as mice reach for and retrieve objects through a narrow slit. The speed and accuracy of the successful movements were quantified across daily sessions. The average speed and the average success rate over time during the training period of the single-pellet reaching task were significantly higher for the control mice compared with $\mathrm{cKO}$ mice $\left(n_{\mathrm{Ctrl}}=10, n_{\mathrm{cKO}}=7\right.$; two-way ANOVA, $p_{\text {speed }}=0.0009, p_{\text {rate }}<0.0001$; Fig. $6 E, F$; see also Movie 2). In fact, the $\mathrm{CKO}$ mice were unable to learn the task because there was no effect of the time on their speed of success (one-way ANOVA, $p=0.1082$; Fig. $6 E$ ) or their rate of success (one-way ANOVA, $p=0.1683$; Fig. $6 F$ ). However, that $\mathrm{cKO}$ mice failed to learn the task was due neither to 
reduced forelimb grip strength $\left(n_{\mathrm{Ctrl}}=12, n_{\mathrm{cKO}}=10\right.$; unpaired $t$ test, $p=0.1266$ ) nor to a lack of interest in reaching the pellet because the number of attempts was not significantly different between groups $\left(n_{\mathrm{Ctrl}}=10, n_{\mathrm{cKO}}=7\right.$; two-way ANOVA, $p=0.0822$, attempts per minute mean for all sessions: Control $=7.98 \pm 0.43 \mathrm{cKO}=9.54 \pm 1.12$ ).

\section{Initial phase of instrumental learning is delayed and PIT is lacking in NMDA-R striatopallidal-deficient mice}

Due to the involvement of the striatum in reward-directed behavior (Balleine et al., 2009; Horvitz, 2009) and the NMDA-R in instrumental (Yin et al., 2005) and Pavlovian conditioning (Parker et al., 2011), we characterized the operant behavior, Pavlovian conditioning, and its interaction in our cKO mice. Fooddeprived mice were exposed to an instrumental protocol in which they had to associate NP action with food outcome (Piccart et al., 2011). We showed that mice in both groups increased NP rates during the instrumental task. However, cKO animals performed significantly fewer NPs during the initial instrumental learning phase $\left(n_{\mathrm{Ctrl}}=15, n_{\mathrm{cKO}}=9\right.$; two-way ANOVA, $p=0.0381$; Fig. $6 G)$. The decreased appetitive response rates of $\mathrm{cKO}$ mice during the first training schedules cannot be related to performance or motor defects because these mice were able to reach higher NP rates in later stages of the training and reached the same performance as controls after 1 month of training $(n \mathrm{CT}=14, n c \mathrm{KO}=$ 8 , unpaired $t$ test, $p=0.7804$; Fig. $6 H$ ), suggesting that the initial delay in NPs may be due to a learning impairment.

In goal-directed behavior, changes in the value of the expected outcome lead to changes in the rate of response to receive the expected outcome, and goal-directed behaviors are sensitive to "goal devaluation" (Balleine and Dickinson, 1998). To evaluate this process, the food restriction diet was stopped to induce outcome devaluation. Both mice groups showed a decrease in NPs $\left(n \mathrm{CT}=14, n c \mathrm{KO}=8\right.$, paired $t$ test, $p_{\mathrm{Ctrl}}<0.0001, p_{\text {cKO }}<$ $0.0001)$, confirming that the behavior was sensitive to devaluation. However, this devaluation was lower for cKO mice (unpaired $t$ test, $p=0.0067$; Fig. $6 H$ ), suggesting that the inactivation of GluN1 in striatopallidal neurons leads to a slower adaptation.

To further characterize the behavioral alteration that indicates either learning or motivation deficits, we performed a PIT paradigm (Bertran-Gonzalez et al., 2013) to distinguish between these two aspects. The first step of PIT uses an appetitive Pavlovian conditioning procedure in which two auditory cues (either a tone noise or a clicker) are paired with the delivery of either a vanillaor chocolate-flavored food pellet. Over the course of training, the mice learned to approach the location of the pellet's delivery selectively and to associate pellet flavors with specific auditory stimuli. Our data show that $\mathrm{cKO}$ and control mice had similar rates of acquisition and performance $\left(n_{\mathrm{CT}}=11, n_{\mathrm{cKO}}=12\right.$; twoway ANOVA, $p=0.8176$ ), suggesting that the phenotype shown by $\mathrm{cKO}$ is not due to altered motivation.

Acquisition curves alone must be interpreted with caution (Gallistel et al., 2004), so we also investigated the motivational behavior of these cKO mice. Pavlovian conditioned responses, including those reflecting the activation of central motivational states, can exert a strong influence on the performance of instrumental actions (Lovibond, 1983; Holland, 2004; Yin et al., 2008). For instance, a conditioned stimulus that predicts food delivery independently can increase instrumental responding for the same food. This effect is commonly studied using the PIT paradigm. In PIT, animals received Pavlovian training phase first, as shown above, followed by the instrumental training phases. In both phases, they learned to associate a cue with food and to press a lever for the same food, respectively. Then, on probe trials, the cue was presented with the lever available and the elevation of response rates in the presence of the conditioned stimulus was measured for both mouse groups. Only control mice selected the action previously associated with the outcome predicted by the stimulus more than the other action; $\mathrm{cKO}$ mice failed the transfer $\left(n_{\mathrm{Ctrl}}=8, n_{\mathrm{cKO}}=11\right.$; Mann-Whitney test, $p=0.0008$; Fig. $\left.6 I\right)$. This provides evidence that iMSN NMDA-Rs are important for associative learning.

\section{Discussion}

Previous studies have shown that striatal NMDA-R plays an important role in locomotor learning, conditioning behaviors, and cognitive flexibility (Dang et al., 2006; Ohtsuka et al., 2008; Jin and Costa, 2010; Parker et al., 2011; Beutler et al., 2011b; Eldred and Palmiter, 2013; Darvas and Palmiter, 2015). Here, for the first time to our knowledge, we address specifically the involvement of iMSN NMDA-Rs in these behaviors. We generated a genetic model allowing specific GluN1 ablation in iMSNs. Using FACS, qRT-PCR, and whole-cell patch-clamp recordings, we confirmed the selective ablation in iMSNs (Durieux et al., 2009, 2012; Ena et al., 2013) by a drastic reduction of GluN1 mRNA and functional inhibition of the NMDA-R current in iMSNs.

At the cellular level, we demonstrate that the loss of GluN1 in iMSNs alters dendrite arborization and synaptic connectivity. Indeed, we observed a decrease in dendritic complexity, spine density, and morphology. As already reported, the NMDA-R deletion in both MSN populations resulted in shorter dendrites and a trend toward fewer branches for each dendrite order (Beutler et al., 2011b). In addition, our findings that the selective deletion of the NMDA-R in iMSNs produces dendritic atrophy are consistent with the fact that dendritic development is largely regulated by glutamate-dependent activity via NMDA-Rs (Sin et al., 2002; Lee et al., 2005; Ewald et al., 2008; Balu et al., 2012; Andreae and Burrone, 2015).

At the synaptic level, the capability of dendritic spines to rapidly respond structurally to transmembrane signals means that they play an important role in learning and memory (Rosi et al., 2008; Chen et al., 2010). Using micromorphometric reconstructions of dendritic endings of cKO neurons, we found a lower spine density and a decrease in the spine volume. Concomitantly, recent data demonstrated that ionotropic glutamate receptor activation is required for spine and synapse formation in iMSNs (Thibault et al., 2015). In addition, we show that decreased dendritic spine density on iMSNs is associated with a loss of functional synaptic connectivity of iMSNs because sEPSC amplitude and frequency were decreased in cKO animals. The reduction in sEPSC frequency in $\mathrm{CKO}$ iMSNs can be explained by the reduction in spine density, whereas the decrease of sEPSC amplitude is due to a reduction in number of its AMPA-Rs associated with smaller head spines. This evidence agrees with previous data in hippocampal CA1 neurons showing that spine enlargement is associated with an increase in AMPA-R-mediated currents and that it is dependent on NMDA-Rs (Matsuzaki et al., 2001). Together, our observations suggest that deficiency in NMDA-R signaling leads to changes in spine density and morphology, as well as EPSC frequency and amplitude. These results emphasize the importance of NMDA-R for the maintenance of synaptic weights and connectivity as well as structure in the iMSN synapses.

The decreased cortical excitatory input to $\mathrm{CKO}$ striatopallidal neurons is partially balanced by an increased output of the iMSNs. Our observations are consistent with several studies showing that NMDA-R deletion induces persistent changes in 
intrinsic excitability. Fan et al. (2005) showed that inactivation of NMDA-Rs enhances the excitability of hippocampal CA3 neurons. Therefore, the occurrence in cKO neurons of such augmentation in cellular excitability is likely due to a negative feedback mechanism that normalizes neuronal output firing despite a reduction in synaptic inputs, thus promoting network stability. This plasticity of intrinsic cellular excitability could be envisaged as an attempt at homeostatic plasticity in the context of reduced excitatory input. Homeostatic regulation of neuronal activity has been shown previously to occur in MSNs during dopamine depletion (Azdad et al., 2009). However, the postnatal NMDA-R deletion may have led to circuit adaptations. Indeed, a recent study has shown that the balance of activity between dMSNs and iMSNs has a direct effect on excitatory innervation of the striatum (Kozorovitskiy et al., 2012). Therefore, the excitatory inputs to both direct and indirect pathways could be altered in GluN1 iMSN KO mice. However, in our case, the decreased activity in iMSNs due to NMDA-R deletion decreases the spine number, whereas the decreased activity in iMSNs due to vesicular GABA transporter deletion or DREADD inactivation increases the spine number (Kozorovitskiy et al., 2012).

The factors that mediate both chemical and structural synaptic plasticity also regulate the connectivity of the cortex to the striatum. Changes in spine morphology and density, as well as in EPSC frequency and amplitude, are consistently found to correlate with cognitive performance. Therefore, we might expect differences in $\mathrm{KO}$ spine and EPSC properties that are likely to correspond with significant behavioral changes in our $\mathrm{CKO}$ mice, as discussed below.

NMDA-R loss in iMSNs induces impairments of environmental and object habituation without alterations in novelty-induced exploration (Eisenstein and Eisenstein, 2006; Salomons et al., 2010). Interestingly, the selective ablation of iMSNs in the dorsomedial part of the striatum (DMS), induced an incremental kinetics in the open field and an increase of the exploration behavior in a decoupled delayed spontaneous object recognition task, indicating an alteration of the habituation process (Durieux et al., 2012).

The striatum also plays a key role in motor learning, mediating the performance of many types of actions, from simple movements to more complicated serial-order behaviors (Rothwell et al., 2015). iMSN NMDA-R is not required for simple motor learning, but its deletion may change the process of action selection within the BG. Interestingly, our results showed that iMSN NMDA-Rs regulate the learning of serial-order tasks and their deletion prevents normal action selection during behavioral tasks without changes in movement initiation and induces alteration of complicated motor learning. This alteration in action selection or fine skill learning is probably due to a lack of inhibition between competing motor programs. During normal behavior, coactivation of both MSN subpopulations is important for action selection, with dMSNs promoting the appropriate motor program and iMSNs inhibiting competing motor programs (Cui et al., 2013). Inhibiting or ablating most iMSNs abolished suppression of inappropriate motor programs and induced hyperkinesia (Durieux et al., 2009, 2012; Bateup et al., 2010). Moreover, Yin et al. (2009) found that iMSNs of the dorsolateral striatum showed an increase in synaptic strength in comparison with dMSNs after motor rotarod training. This increase in synaptic strength in iMSNs resulting from learning was accompanied by an increase in NMDA and AMPA currents. Altogether, these results highlight the requirement of iMSNs as well as the contribution of NMDA-Rs for normal acquisition of motor learning.

The BG have a critical role in goal-directed behavior (Andrzejewski et al., 2004; Schultz, 2004; Horvitz, 2009). Jin and Costa (2010) showed that operant conditioning in striatal NMDA-R cKO mice was impaired. In contrast, Beutler et al. (2011b) showed that this conditioning was completely absent. Importantly, we show that iMSN NMDA-R-deficient mice had a delay in the initial learning phase, but performed similarly to control mice in later stages of training. These results confirm the involvement of iMSNs in the initial learning phase (Durieux et al., 2012). In a recent study, Shan et al. (2014) demonstrated that acquisition of a goal-directed behavior induced plasticity in both dMSNs and iMSNs, specifically in the posterior DMS, but in opposing directions, with a decrease of AMPA/NMDA ratio after learning in iMSNs and an increase of this ratio in dMSNs. First, these results indicate the increased contribution of NMDA-R in iMSNs for the normal acquisition of a goaldirected behavior and support our findings that the inactivation of GluN1 in iMSNs prevents normal goal-directed learning. Second, goal-directed behaviors are sensitive to "goal devaluation" (Balleine and Dickinson, 1998) and our work reveals the role of iMSN NMDA-Rs in the devaluation process.

Our results could be indicative of either a learning deficit or a decrease in motivation, so we investigated the motivational behavior of these cKO mice. Pavlovian conditioned responses, including those reflecting the activation of central motivational states, can exert a strong influence on the performance of instrumental actions (Lovibond, 1983; Holland, 2004). Our data showed that selective NMDA-R deletion in iMSNs completely abolishes Pavlovian cues from augmenting instrumental performance without abolishing Pavlovian or instrumental learning. This suggests that iMSN GluN1 deletion blocks the outcome-selective interaction of Pavlovian and instrumental learning systems.

Together, our data suggest that the NMDA-R deletion leads to the scaling down of structural and functional inputs at corticostriatal synapses, weakening synaptic strength in iMSNs. Weakened synaptic strength alters input integration that leads to the imbalance between direct and indirect pathways and dysfunction in BG output. The reduced cortical drive to iMSNs was partially balanced in these cKO mice by an increase in cellular excitability to normalize neuronal output and promote network stability. Synaptic plasticity and modulation, mediated by NMDA-R, is known to explain enduring changes of synaptic weights in microcircuits important for learning and memory storage (Malenka and Bear, 2004; Barbour et al., 2007; Aceves et al., 2011). Consistent with this view, our cKO mice displayed severe phenotypic alterations in behavior. We propose that the NMDA-R deletion in iMSNs causes a scale-down of the synaptic strength in the indirect pathway, leading to imbalanced input integration between the two striatofugal pathways. This imbalance resulted in robust neurological deficits in functions specifically orchestrated by BG, making the cKO mice less sensitive to changes. In summary, our experiments have identified the highly important function of iMSN NMDA-Rs in the learning and memory of procedures and habits, action selection, and the coordination and storage of motor programs. These receptors are essential for the regulation of learning and adaptation to environment-based experience.

\section{References}

Aceves JJ, Rueda-Orozco PE, Hernandez-Martinez R, Galarraga E, Bargas J (2011) Bidirectional plasticity in striatonigral synapses: a switch to balance direct and indirect basal ganglia pathways. Learn Mem 18:764-773. CrossRef Medline

Albin RL, Young AB, Penney JB (1989) The functional anatomy of basal ganglia disorders. Trends Neurosci 12:366-375. CrossRef Medline

Albin RL, Makowiec RL, Hollingsworth ZR, Dure LS 4th, Penney JB, Young $A B$ (1992) Excitatory amino acid binding sites in the basal ganglia of the rat: a quantitative autoradiographic study. Neuroscience 46:35-48. CrossRef Medline

Andreae LC, Burrone J (2015) Spontaneous neurotransmitter release 
shapes dendritic arbors via long-range activation of NMDA receptors. Cell Rep pii: S2211-S1247(15)00057-1. CrossRef Medline

Andrzejewski ME, Sadeghian K, Kelley AE (2004) Central amygdalar and dorsal striatal NMDA receptor involvement in instrumental learning and spontaneous behavior. Behav Neurosci 118:715-729. CrossRef Medline

Azdad K, Chàvez M, Don Bischop P, Wetzelaer P, Marescau B, De Deyn PP, Gall D, Schiffmann SN (2009) Homeostatic plasticity of striatal neurons intrinsic excitability following dopamine depletion. PLoS One 4:e6908. CrossRef Medline

Balleine BW, Dickinson A (1998) Goal-directed instrumental action: Contingency and incentive learning and their cortical substrates. Neuropharmacology 37:407-419. CrossRef Medline

Balleine BW, Liljeholm M, Ostlund SB (2009) The integrative function of the basal ganglia in instrumental conditioning. Behav Brain Res 199: 43-52. CrossRef Medline

Balu DT, Basu AC, Corradi JP, Cacace AM, Coyle JT (2012) The NMDA receptor co-agonists, D-serine and glycine, regulate neuronal dendritic architecture in the somatosensory cortex. Neurobiol Dis 45:671-682. CrossRef Medline

Barbour B, Brunel N, Hakim V, Nadal JP (2007) What can we learn from synaptic weight distributions? Trends Neurosci 30:622-629. CrossRef Medline

Bateup HS, Santini E, Shen W, Birnbaum S, Valjent E, Surmeier DJ, Fisone G, Nestler EJ, Greengard P (2010) Distinct subclasses of medium spiny neurons differentially regulate striatal motor behaviors. Proc Natl Acad Sci U S A 107:14845-14850. CrossRef Medline

Bearzatto B, Servais L, Roussel C, Gall D, Baba-Aïssa F, Schurmans S, de Kerchove d'Exaerde A, Cheron G, Schiffmann SN (2006) Targeted calretinin expression in granule cells of calretinin-null mice restores normal cerebellar functions. FASEB J 20:380-382. Medline

Benke TA, Lüthi A, Palmer MJ, Wikström MA, Anderson WW, Isaac JT, Collingridge GL (2001) Mathematical modelling of non-stationary fluctuation analysis for studying channel properties of synaptic AMPA receptors. J Physiol 537:407-420. CrossRef Medline

Bertran-Gonzalez J, Laurent V, Chieng BC, Christie MJ, Balleine BW (2013) Learning-related translocation of opioid receptors on ventral striatal cholinergic interneurons mediates choice between goal-directed actions. J Neurosci 33:16060-16071. CrossRef Medline

Beurrier C, Ben-Ari Y, Hammond C (2006) Preservation of the direct and indirect pathways in an in vitro preparation of the mouse basal ganglia. Neuroscience 140:77-86. CrossRef Medline

Beutler LR, Wanat MJ, Quintana A, Sanz E, Bamford NS, Zweifel LS, Palmiter RD (2011) Balanced NMDA receptor activity in dopamine D1 receptor (D1R)- and D2R-expressing medium spiny neurons is required for amphetamine sensitization. Proc Natl Acad Sci U S A 108:4206-4211. CrossRef Medline

Beutler LR, Eldred KC, Quintana A, Keene CD, Rose SE, Postupna N, Montine TJ, Palmiter RD (2011) Severely impaired learning and altered neuronal morphology in mice lacking NMDA receptors in medium spiny neurons. PLoS One 6:e28168. CrossRef Medline

Bolam JP, Hanley JJ, Booth PA, Bevan MD (2000) Synaptic organisation of the basal ganglia. J Anat 196:527-542. CrossRef Medline

Bourin M, Hascoët M (2003) The mouse light/dark box test. Eur J Pharmacol 463:55-65. CrossRef Medline

Cepeda C, André VM, Yamazaki I, Wu N, Kleiman-Weiner M, Levine MS (2008) Differential electrophysiological properties of dopamine D1 and D2 receptor-containing striatal medium-sized spiny neurons. Eur J Neurosci 27:671-682. CrossRef Medline

Chen CC, Gilmore A, Zuo Y (2014) Study motor skill learning by single pellet reaching tasks in mice. J Vis Exp 85. CrossRef Medline

Chen Y, Rex CS, Rice CJ, Dubé CM, Gall CM, Lynch G, Baram TZ (2010) Correlated memory defects and hippocampal dendritic spine loss after acute stress involve corticotropin-releasing hormone signaling. Proc Natl Acad Sci U S A 107:13123-13128. CrossRef Medline

Chintawar S, Hourez R, Ravella A, Gall D, Orduz D, Rai M, Bishop DP, Geuna S, Schiffmann SN, Pandolfo M (2009) Grafting neural precursor cells promotes functional recovery in an SCA1 mouse model. J Neurosci 29: 13126-13135. CrossRef Medline

Cui G, Jun SB, Jin X, Pham MD, Vogel SS, Lovinger DM, Costa RM (2013) Concurrent activation of striatal direct and indirect pathways during action initiation. Nature 494:238-242. CrossRef Medline

Dang MT, Yokoi F, Yin HH, Lovinger DM, Wang Y, Li Y (2006) Disrupted motor learning and long-term synaptic plasticity in mice lacking
NMDAR1 in the striatum. Proc Natl Acad Sci U S A 103:15254-15259. CrossRef Medline

D’Angelo E, De Filippi G, Rossi P, Taglietti V (1995) Synaptic excitation of individual rat cerebellar granule cells in situ: evidence for the role of NMDA receptors. J Physiol 484:397-413. CrossRef Medline

Darvas M, Palmiter RD (2015) Specific contributions of N-methyl-Daspartate receptors in the dorsal striatum to cognitive flexibility. Neuroscience 284:934-942. CrossRef Medline

Day M, Wang Z, Ding J, An X, Ingham CA, Shering AF, Wokosin D, Ilijic E, Sun Z, Sampson AR, Mugnaini E, Deutch AY, Sesack SR, Arbuthnott GW, Surmeier DJ (2006) Selective elimination of glutamatergic synapses on striatopallidal neurons in Parkinson disease models. Nat Neurosci 9: 251-259. CrossRef Medline

Durieux PF, Bearzatto B, Guiducci S, Buch T, Waisman A, Zoli M, Schiffmann SN, de Kerchove d'Exaerde A (2009) D2R striatopallidal neurons inhibit both locomotor and drug reward processes. Nat Neurosci 12: 393-395. CrossRef Medline

Durieux PF, Schiffmann SN, de Kerchove d'Exaerde A (2012) Differential regulation of motor control and response to dopaminergic drugs by $\mathrm{D} 1 \mathrm{R}$ and D2R neurons in distinct dorsal striatum subregions. EMBO J 31:640653. CrossRef Medline

Eisenstein EM, Eisenstein D (2006) A behavioral homeostasis theory of habituation and sensitization: II. Further developments and predictions. Rev Neurosci 17:533-557. Medline

Eldred KC, Palmiter RD (2013) Amphetamine-induced sensitization has little effect on multiple learning paradigms and fails to rescue mice with a striatal learning defect. PLoS One 8:e59964. CrossRef Medline

Ena SL, De Backer JF, Schiffmann SN, de Kerchove d'Exaerde A (2013) FACS array profiling identifies ecto- $5^{\prime}$ nucleotidase as a striatopallidal neuron-specific gene involved in striatal-dependent learning. J Neurosci 33:8794-8809. CrossRef Medline

Everitt BJ, Robbins TW (2005) Neural systems of reinforcement for drug addiction: from actions to habits to compulsion. Nat Neurosci 8: 1481-1489. CrossRef Medline

Ewald RC, Van Keuren-Jensen KR, Aizenman CD, Cline HT (2008) Roles of NR2A and NR2B in the development of dendritic arbor morphology in vivo. J Neurosci 28:850-861. CrossRef Medline

Fan Y, Fricker D, Brager DH, Chen X, Lu HC, Chitwood RA, Johnston D (2005) Activity-dependent decrease of excitability in rat hippocampal neurons through increases in I(h). Nat Neurosci 8:1542-1551. CrossRef Medline

Faraji J, Metz GA (2007) Sequential bilateral striatal lesions have additive effects on single skilled limb use in rats. Behav Brain Res 177:195-204. CrossRef Medline

Gallistel CR, Fairhurst S, Balsam P (2004) The learning curve: implications of a quantitative analysis. Proc Natl Acad Sci U S A 101:13124-13131. CrossRef Medline

Gardoni F, Ghiglieri V, Luca Md, Calabresi P (2010) Assemblies of glutamate receptor subunits with post-synaptic density proteins and their alterations in Parkinson's disease. Prog Brain Res 183:169-182. CrossRef Medline

Gerdeman GL, Partridge JG, Lupica CR, Lovinger DM (2003) It could be habit forming: drugs of abuse and striatal synaptic plasticity. Trends Neurosci 26:184-192. CrossRef Medline

Gerfen CR, Surmeier DJ (2011) Modulation of striatal projection systems by dopamine. Annu Rev Neurosci 34:441-466. CrossRef Medline

Gertler TS, Chan CS, Surmeier DJ (2008) Dichotomous anatomical properties of adult striatal medium spiny neurons. J Neurosci 28:1081410824. CrossRef Medline

Golowasch J, Thomas G, Taylor AL, Patel A, Pineda A, Khalil C, Nadim F (2009) Membrane capacitance measurements revisited: dependence of capacitance value on measurement method in nonisopotential neurons. J Neurophysiol 102:2161-2175. CrossRef Medline

Graybiel AM, Aosaki T, Flaherty AW, Kimura M (1994) The basal ganglia and adaptive motor control. Science 265:1826-1831. CrossRef Medline

Hartveit E, Veruki ML (2007) Studying properties of neurotransmitter receptors by non-stationary noise analysis of spontaneous postsynaptic currents and agonist-evoked responses in outside-out patches. Nat Protoc 2:434-448. CrossRef Medline

Hellemans J, Mortier G, De Paepe A, Speleman F, Vandesompele J (2007) qBase relative quantification framework and software for management and automated analysis of real-time quantitative PCR data. Genome Biol 8:R19. Medline

Heusner CL, Palmiter RD (2005) Expression of mutant NMDA receptors in dopa- 
mine D1 receptor-containing cells prevents cocaine sensitization and decreases cocaine preference. J Neurosci 25:6651-6657. CrossRef Medline

Holland PC (2004) Relations between Pavlovian-instrumental transfer and reinforcer devaluation. J Exp Psychol Anim Behav Process 30:104-117. CrossRef Medline

Horvitz JC (2009) Stimulus-response and response-outcomelearning mechanisms in the striatum. Behav Brain Res 199:129-140. CrossRef Medline

Hyman SE, Malenka RC, Nestler EJ (2006) Neural mechanisms of addiction: the role of reward-related learning and memory. Annu Rev Neurosci 29:565-598. CrossRef Medline

Jin X, Costa RM (2010) Start/stop signals emerge in nigrostriatal circuits during sequence learning. Nature 466:457-462. CrossRef Medline

Kerchner GA, Nicoll RA (2008) Silent synapses and the emergence of a postsynaptic mechanism for LTP. Nat Rev Neurosci 9:813-825. CrossRef Medline

Kozorovitskiy Y, Saunders A, Johnson CA, Lowell BB, Sabatini BL (2012) Recurrent network activity drives striatal synaptogenesis. Nature 485: 646-650. CrossRef Medline

Kravitz AV, Freeze BS, Parker PR, Kay K, Thwin MT, Deisseroth K, Kreitzer AC (2010) Regulation of parkinsonian motor behaviours by optogenetic control of basal ganglia circuitry. Nature 466:622-626. CrossRef Medline

Kravitz AV, Tye LD, Kreitzer AC (2012) Distinct roles for direct and indirect pathway striatal neurons in reinforcement. Nat Neurosci 15:816-818. CrossRef Medline

Kreitzer AC, Malenka RC (2007) Endocannabinoid-mediated rescue of striatal LTD and motor deficits in Parkinson's disease models. Nature 445: 643-647. CrossRef Medline

Lee LJ, Lo FS, Erzurumlu RS (2005) NMDA receptor-dependent regulation of axonal and dendritic branching. J Neurosci 25:2304-2311. CrossRef Medline

Le Merrer J, Rezai X, Scherrer G, Becker JA, Kieffer BL (2013) Impaired hippocampus-dependent and facilitated striatum-dependent behaviors in mice lacking the delta opioid receptor. Neuropsychopharmacology 38:1050-1059. CrossRef Medline

Lovibond PF (1983) Facilitation of instrumental behavior by a Pavlovian appetitive conditioned stimulus. J Exp Psychol Anim Behav Process 9:225-247. CrossRef Medline

Maldonado R, Saiardi A, Valverde O, Samad TA, Roques BP, Borrelli E (1997) Absence of opiate rewarding effects in mice lacking dopamine D2 receptors. Nature 388:586-589. CrossRef Medline

Malenka RC, Bear MF (2004) LTP and LTD: an embarrassment of riches. Neuron 44:5-21. CrossRef Medline

Marty VN, Spigelman I (2012) Long-lasting alterations in membrane properties, $\mathrm{k}(+)$ currents, and glutamatergic synaptic currents of nucleus accumbens medium spiny neurons in a rat model of alcohol dependence. Front Neurosci 6:86. Medline

Matsuzaki M, Ellis-Davies GC, Nemoto T, Miyashita Y, Iino M, Kasai H (2001) Dendritic spine geometry is critical for AMPA receptor expression in hippocampal CA1 pyramidal neurons. Nat Neurosci 4:1086-1092. CrossRef Medline

Monyer H, Sprengel R, Schoepfer R, Herb A, Higuchi M, Lomeli H, Burnashev N, Sakmann B, Seeburg PH (1992) Heteromeric NMDA receptors: molecular and functional distinction of subtypes. Science 256:1217-1221. CrossRef Medline

Ohtsuka N, Tansky MF, Kuang H, Kourrich S, Thomas MJ, Rubenstein JL, Ekker M, Leeman SE, Tsien JZ (2008) Functional disturbances in the striatum by region-specific ablation of NMDA receptors. Proc Natl Acad Sci U S A 105:12961-12966. CrossRef Medline

Parker JG, Beutler LR, Palmiter RD (2011) The contribution of NMDA receptor signaling in the corticobasal ganglia reward network to appetitive Pavlovian learning. J Neurosci 31:11362-11369. CrossRef Medline

Piccart E, Gantois I, Laeremans A, de Hoogt R, Meert T, Vanhoof G, Arckens L, D’Hooge R (2011) Impaired appetitively as well as aversively motivated behaviors and learning in PDE10A-deficient mice suggest a role for striatal signaling in evaluative salience attribution. Neurobiol Learn Mem 95:260-269. CrossRef Medline

Redgrave P, Rodriguez M, Smith Y, Rodriguez-Oroz MC, Lehericy S, Bergman H, Agid Y, DeLong MR, Obeso JA (2010) Goal-directed and habitual control in the basal ganglia: implications for Parkinson's disease. Nat Rev Neurosci 11:760-772. CrossRef Medline

Reynolds JN, Wickens JR (2002) Dopamine-dependent plasticity of corticostriatal synapses. Neural Netw 15:507-521. CrossRef Medline

Rosi S, Andres-Mach M, Fishman KM, Levy W, Ferguson RA, Fike JR (2008)
Cranial irradiation alters the behaviorally induced immediate-early gene Arc (activity-regulated cytoskeleton-associated protein). Cancer Res 68: 9763-9770. CrossRef Medline

Rothwell PE, Hayton SJ, Sun GL, Fuccillo MV, Lim BK, Malenka RC (2015) Input- and output-specific regulation of serial order performance by corticostriatal circuits. Neuron 88:345-356. CrossRef Medline

Salomons AR, van Luijk JA, Reinders NR, Kirchhoff S, Arndt SS, Ohl F (2010) Identifying emotional adaptation: behavioural habituation to novelty and immediate early gene expression in two inbred mouse strains. Genes Brain Behav 9:1-10. CrossRef Medline

Schiffmann SN, Fisone G, Moresco R, Cunha RA, Ferré S (2007) Adenosine A2A receptors and basal ganglia physiology. Prog Neurobiol 83:277-292. CrossRef Medline

Schultz W (2004) Neural coding of basic reward terms of animal learning theory, game theory, microeconomics and behavioural ecology. Curr Opin Neurobiol 14:139-147. CrossRef Medline

Seutin V, Engel D (2010) Differences in $\mathrm{Na}+$ conductance density and $\mathrm{Na}+$ channel functional properties between dopamine and GABA neurons of the rat substantia nigra. J Neurophysiol 103:3099-3114. CrossRef Medline

Shan Q, Ge M, Christie MJ, Balleine BW (2014) The acquisition of goaldirected actions generates opposing plasticity in direct and indirect pathways in dorsomedial striatum. J Neurosci 34:9196-9201. CrossRef Medline

Sholl DA (1953) Dendritic organization in the neurons of the visual and motor cortices of the cat. J Anat 87:387-406. Medline

Sin WC, Haas K, Ruthazer ES, Cline HT (2002) Dendrite growth increased by visual activity requires NMDA receptor and Rho GTPases. Nature 419:475-480. CrossRef Medline

Sloan AM, Fink MK, Rodriguez AJ, Lovitz AM, Khodaparast N, Rennaker RL, Hays SA (2015) A within-animal comparison of skilled forelimb assessments in rats. PLoS One 10:e0141254. CrossRef Medline

Srinivas S, Watanabe T, Lin CS, William CM, Tanabe Y, Jessell TM, Costantini F (2001) Cre reporter strains produced by targeted insertion of EYFP and ECFP into the ROSA26 locus. BMC Dev Biol 1:4. CrossRef Medline

Standaert DG, Friberg IK, Landwehrmeyer GB, Young AB, Penney JB Jr (1999) Expression of NMDA glutamate receptor subunit mRNAs in neurochemically identified projection and interneurons in the striatum of the rat. Brain Res Mol Brain Res 64:11-23. CrossRef Medline

Surmeier DJ, Ding J, Day M, Wang Z, Shen W (2007) D1 and D2 dopaminereceptor modulation of striatal glutamatergic signaling in striatal medium spiny neurons. Trends Neurosci 30:228-235. CrossRef Medline

Tepper JM, Sharpe NA, Koós TZ, Trent F (1998) Postnatal development of the rat neostriatum: electrophysiological, light- and electron-microscopic studies. Dev Neurosci 20:125-145. CrossRef Medline

Tepper JM, Abercrombie ED, Bolam JP (2007) Basal ganglia macrocircuits. Prog Brain Res 160:3-7. CrossRef Medline

Thibault D, Giguère N, Loustalot F, Bourque MJ, Ducrot C, El Mestikawy S, Trudeau LÉ (2015) Homeostatic regulation of excitatory synapses on striatal medium spiny neurons expressing the D2 dopamine receptor. Brain Struct Funct. In press.

Thompson RF, Spencer WA (1966) Habituation: a model phenomenon for the study of neuronal substrates of behavior. Psychological Review 73: 16-43. CrossRef Medline

Wall NR, De La Parra M, Callaway EM, Kreitzer AC (2013) Differential innervation of direct- and indirect-pathway striatal projection neurons. Neuron 79:347-360. CrossRef Medline

Whishaw IQ, O'Connor WT, Dunnett SB (1986) The contributions of motor cortex, nigrostriatal dopamine and caudate-putamen to skilled forelimb use in the rat. Brain 109:805-843. CrossRef Medline

Yin HH, Knowlton BJ (2006) The role of the basal ganglia in habit formation. Nat Rev Neurosci 7:464-476. CrossRef Medline

Yin HH, Knowlton BJ, Balleine BW (2005) Blockade of NMDA receptors in the dorsomedial striatum prevents action-outcome learning in instrumental conditioning. Eur J Neurosci 22:505-512. CrossRef Medline

Yin HH, Ostlund SB, Balleine BW (2008) Reward-guided learning beyond dopamine in the nucleus accumbens: the integrative functions of cortico-basal ganglia networks. Eur J Neurosci 28:1437-1448. CrossRef Medline

Yin HH, Mulcare SP, Hilário MR, Clouse E, Holloway T, Davis MI, Hansson AC, Lovinger DM, Costa RM (2009) Dynamic reorganization of striatal circuits during the acquisition and consolidation of a skill. Nat Neurosci 12:333-341. CrossRef Medline 